\title{
Platinum Complexes of 5,6-dihydroacenaphtho[5,6-cd]-1,2-dichalcogenoles
}

\author{
Callum G. M. Benson, Catherine M. Schofield, Rebecca A. M. Randall, Lucy \\ Wakefield, Fergus R. Knight, Alexandra M. Z. Slawin and J. Derek Woollins*
}

Keywords: Chalcogen / Metathesis / Platinum / X-ray structure / Acenaphthene / Coordination complex

\begin{abstract}
Six platinum bisphosphine complexes, bearing dichalcogen acenaphthene ligands, have been prepared by metathesis from cis$\left[\mathrm{PtCl}_{2}\left(\mathrm{PR}_{3}\right)_{2}\right]\left(\mathrm{R}_{3}=\mathrm{Ph}_{3}, \mathrm{Ph}_{2} \mathrm{Me}, \mathrm{PhMe}_{2}\right)$ and the dilithium salts of the parent 5,6-dihydroacenaphtho[5,6-cd]-1,2-dichalcogenoles [AcenapE $E_{2}$ ( $(\mathbf{L 1} \mathrm{E}=\mathrm{S}, \mathbf{L 2} \mathrm{E}=\mathrm{Se})$. For their synthesis, the appropriate disulfide or diselenide species was treated with super hydride $\left[\mathrm{LiBEt}_{3} \mathrm{H}\right]$ affording the dilithium salt by in situ reduction of the AcenapE $_{2}$ E-E bond. Further reaction, via metathetical addition to the cis-platinum precursor afforded the respective platinum(II) complex $\left[\mathrm{Pt}\left(5,6-\mathrm{AcenapE}_{2}\right)\left(\mathrm{PR}_{3}\right)_{2}\right]\left(\mathrm{R}_{3}=\mathrm{Ph}_{3}: \mathrm{E}=\mathrm{S} \mathbf{1}\right.$, Se 2; $\mathrm{R}_{3}=\mathrm{Ph}_{2} \mathrm{Me}: \mathrm{E}=\mathrm{S} \mathrm{3}, \mathrm{Se}$ 4; $\mathrm{R}_{3}=\mathrm{PhMe}_{2}: \mathrm{E}=\mathrm{S} \mathrm{5}$, Se 6).
\end{abstract}

\begin{abstract}
All six complexes have been fully characterised, principally by multinuclear magnetic resonance spectroscopy, IR and MS. Selenium complexes $\mathbf{4}$ and $\mathbf{6}$ provide examples of AA'X spin systems, as displayed by their ${ }^{31} \mathrm{P}\left\{{ }^{1} \mathrm{H}\right\}$ NMR spectra. X-ray structures were determined for L1, L2, 1, 2, 5 and 6 and analysed, where appropriate, by platinum metal geometry, periatom displacement, splay angle magnitude, acenaphthene ring torsion angles and $\mathrm{E} \cdots \mathrm{E}$ interactions. Platinum was found to adopt a distorted square-planar geometry in all four complexes, with the nature of the Acenap $\mathrm{E}_{2}$ ligand playing little part in the conformation of the substituents bound to the trivalent phosphorus atoms.
\end{abstract}

[a] EASTChem, School of Chemistry, University of St Andrews, St Andrews, Fife, KY16 9ST, UK.

Fax: (+44)1334 463384

E-mail: jdw3@st-and.ac.uk

Supporting information for this article is available on the WWW under http://www.eurjic.org/ or from the author.

\section{Introduction}

The coordination chemistry of peri-substituted naphthalenes and structurally related systems has been developed over the last 15 years.[1] Geometric constraints unique to these frameworks are imposed by a double substitution at the peri-positions (positions 1 and 8 of the naphthalene ring, 5 and 6 of acenaphthene),[2,3] placing large heteroatoms or groups in close proximity, usually within van der Waals radii.[4] A number of investigators have utilised this characteristic of the naphthalene scaffold to study bonding interactions in main group systems, where molecular geometry is determined by a competition between attractive (covalent and weak) forces and repulsive interactions (steric strain).[5,6] The distinguishing feature of peri-substitution is the ability to achieve a relaxed geometry via formation of a direct bond between the two peri-atoms.[7] Furthermore, proximity effects associated with peri-substitution favours complexation to a bridging metal species, providing the correct spacial arrangement for bidentate coordination.

Transition metal complexes incorporating 1,8-disubstituted naphthalene ligands have been well documented,[1] with the majority of examples reported bearing either bis(phosphine) or bis(thiolate) functionalities. Complexes assembled from ligands with Group 16 donor atoms invariably contain the naphthalene-1,8dichalcogenole synthon, $\mathrm{NapE}_{2} \cdot[1]$ Initial investigations were undertaken by the group of Teo, examining the extensive redox chemistry of tetrathionaphthalene (TTN), tetrachlorotetrathionaphthalene (TCTTN) and tetrathiotetracene (TTT) by preparing a series of singly and doubly bridged platinum and iridium complexes.[8] Further complexes bearing TTN type ligands were prepared coordinated to $\mathrm{Fe}$, Co and Ni.[9] Similarly, oxidative addition of $\left[\mathrm{Pd}\left(\mathrm{PPh}_{3}\right)_{3}\right]$ and $\left[\mathrm{Pt}\left(\mathrm{PPh}_{3}\right)_{4}\right]$ to the related hexachloronaphthalene-1,8-dithiole (hcdtn) ligand affords two mononuclear square-planar complexes,[10,11] whilst treatment with $\mathrm{RhCl}\left(\mathrm{PPh}_{3}\right)_{3}$ results in the formation of a five-coordinate $\mathrm{Rh}(\mathrm{III})$ complex.[11] In comparison, reaction of hcdtn with [Ni(cod $\left.)_{2}\right]$ and $\mathrm{PPh}_{3}$ affords a memorable trinuclear nickel(II) complex.[10]

During our investigations of peri-substituted naphthalenes, we prepared a series of platinum bisphosphine complexes bearing dichalcogen-derivatised naphthalene, acenaphthene and phenanthrene ligands via oxidative addition to zero-valent platinum species and from metathetical methods involving reaction with cis$\left[\mathrm{PtCl}_{2}\left(\mathrm{PR}_{3}\right)_{2}\right]$.[12] In a comparative study, we reported a series of binuclear iridium(II) complexes, synthesised from the oxidative reactions of similar dithiole ligands with $\left[\{\operatorname{Ir}(\mu-\mathrm{Cl})(\operatorname{cod})\}_{2}\right] .[13]$ To supplement our initial platinum study, $\left[\mathrm{NapS}_{2} \mathrm{Pt}\left(\mathrm{PPh}_{3}\right)_{2}\right]$ was further treated with a range of $\mathrm{Pt}, \mathrm{Pd}, \mathrm{Rh}, \mathrm{Ir}$ and Mo complexes to afford a series of bimetallic complexes containing an $\mathrm{MM}^{\top} \mathrm{S}_{2}$ core.[14] The corresponding reactions with $\left[\mathrm{AuPPh}_{3}\right] \mathrm{ClO}_{4}$ and $\mathrm{AgClO}_{4}$ afforded binuclear and tetranuclear gold clusters and tri- or tetranuclear silver clusters, the outcome dependent upon the stoichiometry of the reactants.[15] Further examples of multimetallic complexes bearing naphthalene dithiolate ligands have been reported in the literature, with examples of tetra- and pentanuclear copper(I) complexes of 1,8-naphthalene dithiolate[16] and oligmomeric, dimeric and monomeric zinc complexes of 2,7di-tert-butylnaphtho[1,8-c,d][1,2]dithiole and naphthoic anhydride 
dithiole.[17] We have also prepared a series of titanocene complexes incorporating a range of dithioles with modified naphthalene-1,8-yl backbones, via oxidative addition reactions involving $\mathrm{TiCp}_{2}(\mathrm{CO})_{2} \cdot[18] \mathrm{A}$ homologous series of three Group 4 metallocene complexes was also achieved from $\left[\mathrm{MCp}_{2} \mathrm{Cl}_{2}\right](\mathrm{M}=$ Ti, Zr, Hf).[19]

Whilst the coordination chemistry of sterically crowded 1,8disubstituted naphthalenes has been well investigated, complexes formed from related peri-substituted 1,2-dihydroacenaphthylenes (acenaphthene)[3] have received much less attention. Our recent work has focused on the acenaphthene skeleton investigating chalcogen-tin compounds[20] and related halogen-chalcogen and chalcogen-chalcogen derivatives,[21] which were shown to be ideal building blocks for the construction of silver(I) coordination complexes and extended networks.[22] Here in we describe the preparation and structural analysis of six platinum bisphosphine complexes $\left[\mathrm{Pt}\left(5,6-\mathrm{AcenapE}_{2}\right)\left(\mathrm{PR}_{3}\right)_{2}\right]\left(\mathrm{R}_{3}=\mathrm{Ph}_{3}: \mathrm{E}=\mathrm{S} \mathbf{1}\right.$, Se 2; $\mathrm{R}_{3}=$ $\mathrm{Ph}_{2} \mathrm{Me}: \mathrm{E}=\mathrm{S}$ 3, Se 4; $\mathrm{R}_{3}=\mathrm{PhMe}_{2}: \mathrm{E}=\mathrm{S}$ 5, Se 6) formed by metathetical methods from 5,6-dihydroacenaphtho[5,6-cd]-1,2dichalcogenoles [AcenapE $\mathrm{E}_{2}$ ] $(\mathbf{L} 1 \mathrm{E}=\mathrm{S}, \mathbf{L 2} \mathrm{E}=\mathrm{Se})$ and cis$\left[\mathrm{PtCl}_{2}\left(\mathrm{PR}_{3}\right)_{2}\right]\left(\mathrm{R}_{3}=\mathrm{Ph}_{3}, \mathrm{Ph}_{2} \mathrm{Me}, \mathrm{PhMe}_{2}\right)($ Scheme 1).

\section{Results and Discussion}

Platinum bisphosphine complexes 1-6 bearing 5,6dihydroacenaphtho[5,6-cd]-1,2-dichalcogenoles [AcenapE $\left.\mathrm{A}_{2}\right](\mathbf{L 1} \mathrm{E}$ $=\mathrm{S}, \mathbf{L} 2 \mathrm{E}=\mathrm{Se}$ ) have been prepared by metathesis from cis$\left[\mathrm{PtCl}_{2}\left(\mathrm{PR}_{3}\right)_{2}\right]\left(\mathrm{R}_{3}=\mathrm{Ph}_{3}, \mathrm{Ph}_{2} \mathrm{Me}, \mathrm{PhMe}_{2}\right)$ and the dilithium salts of the parent dichalcogen acenaphthene ligands (Scheme 1). All six complexes 1-6 and ligands $\mathbf{L} 1$ and $\mathbf{L} 2$ were synthesised and fully characterised, principally by multinuclear magnetic resonance and IR spectroscopy and mass spectrometry. The homogeneity of the new compounds was, where possible, confirmed by microanalysis.

5,6-Dihydroacenaphtho[5,6-cd]-1,2-dithiole $\left(\right.$ AcenapS $\left._{2}\right) \mathbf{L 1}$ and 5,6-dihydroacenaphtho[5,6-cd]-1,2-diselenole $\quad\left(\right.$ AcenapSe $\left._{2}\right) \quad \mathbf{L 2}$ were prepared following standard literature procedures[23] starting from 5,6-dibromoacenaphthene.[24] Synthesis of the platinum metal complexes was based on previously well documented routes to complexes of 1,8-disubstituted naphthalene chalcogenides and related polyaromatic hydrocarbon compounds.[12] For their synthesis, the appropriate 5,6-dihydroacenaphtho[5,6-cd]-1,2dichalcogenole was treated with two equivalents of super hydride $\left[\mathrm{LiBEt}_{3} \mathrm{H}\right]$ in tetrahydrofuran, at room temperature, generating a reactive dilithium intermediate via in situ reduction of the E-E bond. Subsequent metathetical addition to the desired cis-platinum precursor afforded the respective platinum(II) complex $[\mathrm{Pt}(5,6-$ AcenapE $\left.\left.{ }_{2}\right)\left(\mathrm{PR}_{3}\right)_{2}\right]\left(\mathrm{R}_{3}=\mathrm{Ph}_{3}: \mathrm{E}=\mathrm{S} \mathrm{1}\right.$, Se 2; $\mathrm{R}_{3}=\mathrm{Ph}_{2} \mathrm{Me}: \mathrm{E}=\mathrm{S} \mathrm{3}$, Se 4; $\mathrm{R}_{3}=\mathrm{PhMe}_{2}: \mathrm{E}=\mathrm{S} \mathrm{5}$, Se 6) in good to moderate yields (43$76 \%$; Scheme 1).

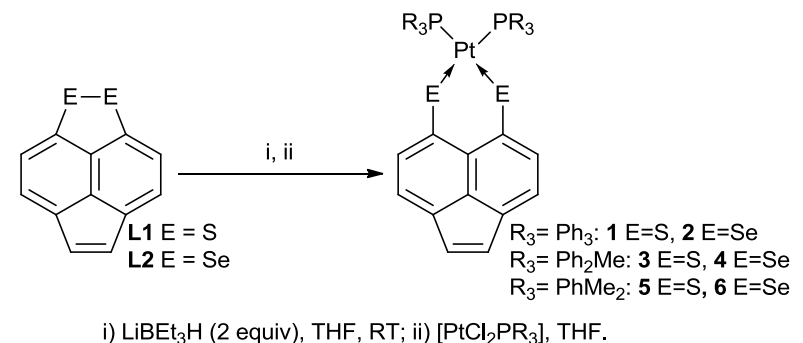

Scheme 1. Reaction scheme for the preparation of bisphosphine complexes $\left[\mathrm{Pt}\left(5,6-\mathrm{AcenapE}_{2}\right)\left(\mathrm{PR}_{3}\right)_{2}\right]$ 1-6 bearing 5,6-dihydroacenaphtho[5,6-cd]-1,2dichalcogenoles $\mathbf{L} \mathbf{1}$ and $\mathbf{L} 2$.
${ }^{31} \mathrm{P}\left\{{ }^{1} \mathrm{H}\right\}$ NMR spectroscopic data for the series of bisphoshine complexes is displayed in Table 1 . The spectra of complexes $\mathbf{1}, \mathbf{3}$ and $\mathbf{5}$, bearing the sulfur ligand $\mathbf{L 1}$, display anticipated single resonances with platinum satellites, moving to lower chemical shifts as the alkyl group on phosphorus is varied from $\mathrm{R}_{3}=\mathrm{Ph}_{3}$ to $\mathrm{R}_{3}=\mathrm{PhMe}_{2}\left[\mathbf{1} \delta=23.52 \mathrm{ppm},{ }^{1} J\left({ }^{31} \mathrm{P},{ }^{195} \mathrm{Pt}\right)=2980 \mathrm{~Hz} ; \mathbf{3} \delta=4.51\right.$ ppm, ${ }^{1} J\left({ }^{31} \mathrm{P},{ }^{195} \mathrm{Pt}\right)=2926 \mathrm{~Hz} ; 5 \delta=-13.14 \mathrm{ppm}{ }^{1} J\left({ }^{31} \mathrm{P},{ }^{195} \mathrm{Pt}\right)=2861$ $\mathrm{Hz}$. A decrease in the coupling constants of the platinum satellites is also observed going from $\mathrm{Ph}_{3}$ to $\mathrm{PhMe}_{2}$, consistent with the decrease in electronegativity of the alkyl substituents and an apparent decrease in the $s$-character of the bond.[25]

Table $1 .{ }^{31} \mathrm{P}\left\{{ }^{1} \mathrm{H}\right\}$ NMR spectroscopic data for complexes 1-6. [a]

\begin{tabular}{lllllll}
\hline & 1 & 2 & 3 & 4 & 5 & 6 \\
\hline${ }^{31} \mathrm{P} N M R$ & 23.52 & 20.19 & 4.51 & 1.22 & $\begin{array}{l}13.1 \\
4\end{array}$ & -16.22 \\
${ }^{1} J\left({ }^{31} \mathrm{P}-{ }^{195} \mathrm{Pt}\right)$ & 2980 & 3020 & 2926 & 2958 & 2861 & 2861 \\
${ }^{2} J\left({ }^{31} \mathrm{P}-{ }^{77} \mathrm{Se}\right)$ & - & - & - & - & - & $47($ cis $) ; 56($ trans $)$ \\
\hline
\end{tabular}

[a] $\delta(\mathrm{ppm}), J(\mathrm{~Hz})$.

Platinum complexes 2, 4 and $\mathbf{6}$, containing two phosphine ligands and the symmetrical bis-selenium ligand $\mathbf{L 2}$, can be analysed as AA'X spin systems (disregarding satellites for ${ }^{31} \mathrm{P} /{ }^{77} \mathrm{Se}-{ }^{195} \mathrm{Pt}$ coupling; Figure 1).[26] The AA nuclei correspond to the two ${ }^{31} \mathrm{P}$ atoms which align with either a cis or trans configuration with respect to the low abundant ${ }^{77} \mathrm{Se}$ NMR active isotope, the X-nucleus in the spin system (Figure 1). The presence of the NMR-inactive isotopomer of the $\mathrm{X}$-nucleus at the second $\mathrm{Se}$ coordinating site thus breaks the symmetry of the molecule and ensures the two ${ }^{31} \mathrm{P}$ environments are magnetically inequivalent. This secondary isotopomer effect, combined with the presence of weak ${ }^{31} \mathrm{P}-{ }^{31} \mathrm{P}$ coupling, creates a complex satellite system observed in both the ${ }^{31} \mathrm{P}$ and ${ }^{77} \mathrm{Se}$ NMR spectra of these compounds (Figure $1)$.

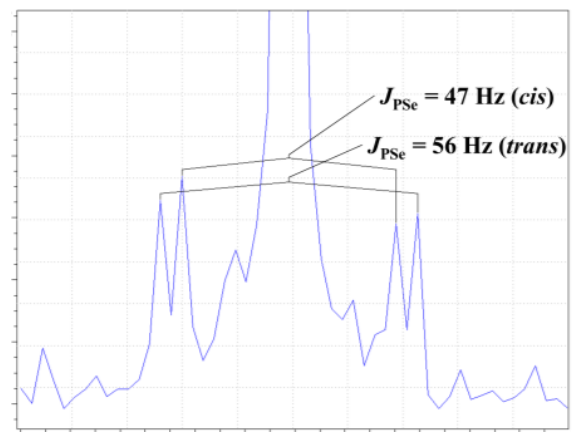

Figure 1. An expansion of the ${ }^{31} \mathrm{P}\left\{{ }^{1} \mathrm{H}\right\}$ NMR spectrum of complex 6 showing the satellites for cis and trans $\left.{ }^{2} J{ }^{31} \mathrm{P},{ }^{77} \mathrm{Se}\right)$ coupling of an $\mathrm{AA} \cdot \mathrm{X}$ spin system (the satellites for the large ${ }^{1} J\left({ }^{31} \mathrm{P},{ }^{195} \mathrm{Pt}\right)$ coupling are omitted for clarity).

Difficulties obtaining data with sufficiently good enough signalto-noise ratios resulted in the expected AA'X pattern not being fully resolved in the ${ }^{31} \mathrm{P}\left\{{ }^{1} \mathrm{H}\right\}$ NMR spectrum of complex 4 . Nevertheless, the standard single resonance (corresponding to molecules containing NMR-inactive Se nuclei) was observed, lying upfield with respect to the equivalent sulfur complex $\mathbf{3}$ and with expected satellites for ${ }^{1} J\left({ }^{31} \mathrm{P},{ }^{195} \mathrm{Pt}\right)$ coupling $[4 \delta=1.22 \mathrm{ppm}$, $\left.{ }^{1} J\left({ }^{31} \mathrm{P},{ }^{195} \mathrm{Pt}\right)=2958 \mathrm{~Hz}\right]$. 
Table 2. Selected interatomic distances $[\AA]$ and angles $\left[^{\circ}\right]$ for $\mathbf{L 1}, \mathbf{L 2}, \mathbf{1}, \mathbf{2}, \mathbf{5}, \mathbf{6}$

\begin{tabular}{|c|c|c|c|c|c|c|}
\hline Compound & L1 & $\mathrm{L} 2$ & 1 & 2 & 5 & 6 \\
\hline Ligand; peri-atoms & SS & $\mathrm{SeSe}$ & L1; SS & $\mathbf{L 2}, \mathrm{SeSe}$ & L1; SS & L2, SeSe \\
\hline $\mathrm{E}(1) \cdots \mathrm{E}(9)$ & $2.1025(19)$ & $2.400(2)[2.380(2)]$ & $3.267(4)$ & $3.437(3)$ & $3.273(7)$ & $3.418(3)$ \\
\hline$\Sigma r_{\mathrm{vdW}}-\mathrm{E}(1) \cdots \mathrm{E}(9)^{\mathrm{a}} ; \% \Sigma \mathrm{r}_{\mathrm{vdw}}[\mathrm{a}]$ & $1.498 ; 58$ & $1.400 ; 63[1.420 ; 63]$ & $0.333 ; 91$ & $0.363 ; 90$ & $0.325 ; 91$ & $0.381 ; 90$ \\
\hline \multicolumn{7}{|l|}{ Peri-region bond angles } \\
\hline $\mathrm{E}(1)-\mathrm{C}(1)-\mathrm{C}(10)$ & $113.6(3)$ & $114.0(9)[117.4(9)]$ & $125.7(7)$ & $127.2(12)$ & 127.1(11) & $131.0(10)$ \\
\hline $\mathrm{C}(1)-\mathrm{C}(10)-\mathrm{C}(9)$ & $120.2(5)$ & $128.0(11)[122.6(11)]$ & $128.9(8)$ & $128.0(13)$ & $128.7(12)$ & $129.5(11)$ \\
\hline $\mathrm{E}(9)-\mathrm{C}(9)-\mathrm{C}(10)$ & $114.4(4)$ & $114.9(9)[116.3(10)]$ & $127.9(6)$ & $130.5(10)$ & $128.0(11)$ & $125.9(10)$ \\
\hline$\Sigma$ of bay angles & $348.2(7)$ & $356.9(17)[356.3(17)]$ & $382.5(12)$ & $385.7(20)$ & $383.8(20)$ & $386.4(18)$ \\
\hline Splay angle ${ }^{\mathrm{b}}$ & -11.8 & $-3.1[-3.7]$ & 22.5 & 25.7 & 23.8 & 26.4 \\
\hline \multicolumn{7}{|l|}{ Out-of-plane displacement } \\
\hline $\mathrm{E}(1)$ & $0.022(1)$ & $-0.053(1)[-0.061(1)]$ & $0.170(1)$ & $0.155(1)$ & $0.044(1)$ & $0.157(1)$ \\
\hline $\mathrm{E}(9)$ & $0.003(1)$ & $-0.032(1)[0.023(1)]$ & $0.075(1)$ & $0.015(1)$ & $0.127(1)$ & $0.014(1)$ \\
\hline \multicolumn{7}{|c|}{ Central naphthalene ring torsion angles } \\
\hline $\mathrm{C}:(6)-(5)-(10)-(1)$ & $179.84(1)$ & $178.96(1)[177.76(1)]$ & $177.98(1)$ & 178.51(1) & $179.37(1)$ & $177.36(1)$ \\
\hline $\mathrm{C}:(4)-(5)-(10)-(9)$ & $179.55(1)$ & $178.69(1)[177.07(1)]$ & $-179.97(1)$ & $178.25(1)$ & $178.04(1)$ & $173.18(1)$ \\
\hline
\end{tabular}

[a] van der Waals radii used for calculations: $\left.\mathrm{r}_{\mathrm{vdW}}(\mathrm{S}) 1.80 \AA \mathrm{r}_{\mathrm{vdw}}(\mathrm{Se}) 1.90 \AA \mathrm{A}^{2}\right]^{b}$ Splay angle: $\Sigma$ of the three bay region angles -360 .

In comparison, the ${ }^{31} \mathrm{P}\left\{{ }^{1} \mathrm{H}\right\}$ NMR spectra of complexes 2 and 6 display the expected pattern for the $\mathrm{AA}^{\top}$ nuclei of an $\mathrm{AA}^{\top} \mathrm{X}$ spin system.[26] In addition to the established single resonances accompanied by platinum satellites $[2 \delta=20.19 \mathrm{ppm}$, ${ }^{1} J\left({ }^{31} \mathrm{P},{ }^{195} \mathrm{Pt}\right)=3020 \mathrm{~Hz} ; 6 \delta=-16.22 \mathrm{ppm},{ }^{1} J\left({ }^{31} \mathrm{P},{ }^{195} \mathrm{Pt}\right)=2861$ $\mathrm{Hz}$, satellites for ${ }^{77} \mathrm{Se}$ coupling are also present in both spectra. In the spectrum of complex $\mathbf{6}$, two sets of ${ }^{77} \mathrm{Se}$ satellites are clearly present, with ${ }^{2} J\left({ }^{31} \mathrm{P},{ }^{77} \mathrm{Se}\right)$ values of $47 \mathrm{~Hz}$ and $56 \mathrm{~Hz}$ corresponding to the cis and trans couplings (Figure 1). Whilst it is impossible to assign the two distinct satellites as being either trans or cis to the ${ }^{77} \mathrm{Se}$ nuclei in the system, the $J$ values are consistent with those found in the naphthalene analogue $\left[\mathrm{Pt}\left(1,8-\mathrm{Se}_{2}-\mathrm{nap}\right)\left(\mathrm{PMe}_{3}\right)_{2}\right](47 \mathrm{~Hz}$ and $53 \mathrm{~Hz})$. In contrast, the ${ }^{2} J\left({ }^{31} \mathrm{P},{ }^{77} \mathrm{Se}\right)$ cis/trans coupling constants for complex 2 are of a similar magnitude, thus resulting in an overlap of the satellites in the ${ }^{31} \mathrm{P}$ NMR spectrum, making exact values for the two couplings difficult to extract. ${ }^{1} J\left({ }^{31} \mathrm{P}_{\mathrm{A}},{ }^{31} \mathrm{P}_{\mathrm{A}}\right)$ coupling constants are notoriously small for $\mathrm{AA}^{\prime} \mathrm{X}$ spin systems[27] and were not observed in the ${ }^{31} \mathrm{P}\left\{{ }^{1} \mathrm{H}\right\}$ NMR spectra of complexes $2, \mathbf{4}$ and $\mathbf{6}$. The partial solubility of the complexes also made obtaining ${ }^{77} \mathrm{Se}$ NMR spectra with reasonable signal-to-noise ratios for these complexes problematic.

X-ray investigations: Crystals of $\mathbf{L 1}$ and $\mathbf{L 2}$ suitable for Xray diffraction were obtained from hot hexane followed by cooling at $-10^{\circ} \mathrm{C}$ overnight. In addition, single crystals for complexes 1, 2, 5 and $\mathbf{6}$ were obtained by diffusion of hexane into saturated solutions of the individual compound in dichloromethane. Selenium ligand L2 contains two nearly identical molecules in the asymmetric unit; all other compounds contain one molecule in the asymmetric unit. Selected interatomic distances, angles and torsion angles are listed in Tables 2 and 3. Further crystallographic information can be found in Table 4 and in the Electronic Supporting Information (ESI).

5,6-dihydroacenaphtho[5,6-cd]-1,2-dichalcogenoles [AcenapE $E_{2}$ ] L1 $(E=S)$ and $\mathbf{L 2}(E=S e)$ (Figure 2) unsurprisingly adopt similar molecular structures to naphthalene equivalents $\mathrm{NapE}_{2}$.[29] Nevertheless, introduction of the ethane linkage at the 1,2-positions in the acenaphthene molecules naturally reduces the C4-C5-C6 bond angle (L1/L2 114\%113 cf. $\mathrm{NapS}_{2} / \mathrm{NapSe}_{2} \quad 125^{\circ} / 123^{\circ}$ )[29] whilst simultaneously increasing the C1-C10-C9 angular splay (L1/L2 120\%128 ; $f$. $\mathrm{NapS}_{2} / \mathrm{NapSe}_{2} 118^{\circ} / 122^{\circ}$ ),[29] consequently elongating the short S-S and Se-Se peri-bonds in these "simple" single bonded

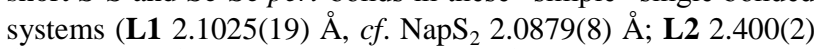
$\AA$ [2.380(2) ̊̊], cf. $\mathrm{NapSe}_{2} 2.3639(5) \AA$ )..[29] Steric demands imposed by the substitution of heavy chalcogen atoms are relieved in these systems by the formation of such strong E-E covalent bonds, regardless of the minor increase in their length. In the sulfur analogue L1, this is accompanied by a large negative splay angle as the exocyclic peri-bonds naturally converge $\left(-11.8^{\circ} \quad c f\right.$. $\left.\mathrm{NapS}_{2}-11.2^{\circ}\right)$, and only a minor displacement of the sulfur atoms from the mean plane of the organic backbone, in line with the naphthalene compound (0.01$0.02 \AA$ A).[29] Typical for systems incorporating larger substituents, the selenium counterpart L2 exhibits a more positive splay angle $\left(-3.1^{\circ}\left[-3.7^{\circ}\right], c f . \mathrm{NapSe}_{2}-3.6^{\circ}\right)[29]$ with the two $\mathrm{E}^{-\mathrm{C}_{\text {Acenap }}}$ bonds now adopting a more parallel alignment. Buckling of the two naturally planar carbon frameworks is minimal and comparable to the naphthalene compounds, with the greatest distortion observed in the selenium analogue $\mathbf{L 2}$; maximum C-C-C-C central acenaphthene torsion angles in the range $178-179^{\circ}$.
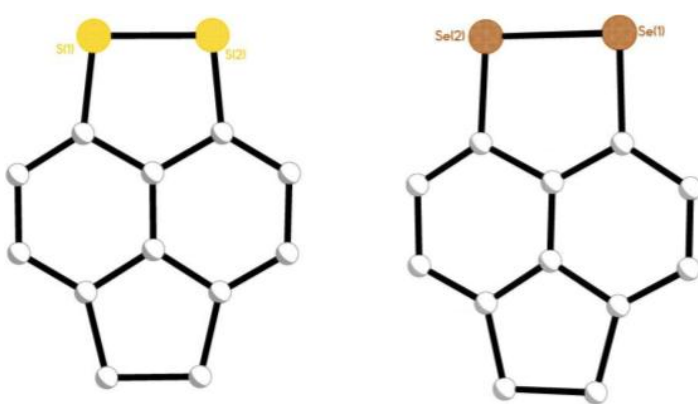

Figure 2. The molecular structures of 5,6-dihydroacenaphtho[5,6-cd]1,2-dichalcogenoles [AcenapE $\left.\mathrm{E}_{2}\right](\mathbf{L} 1 \mathrm{E}=\mathrm{S}, \mathbf{L} 2 \mathrm{E}=\mathrm{Se} ; \mathrm{H}$ atoms omitted for clarity). 
Table 3. Platinum coordination geometry; selected intramolecular distances $[\AA ̊]$ and angles $\left[{ }^{\circ}\right]$ for $\mathbf{1}, \mathbf{2}, \mathbf{5}, \mathbf{6}$

\begin{tabular}{lllll}
\hline Complex & 1 & 2 & 5 & 6 \\
\hline Ligand; peri-atoms & L1; SS & L2, SeSe & L1; SS & L2, SeSe \\
Metal geometry-bond & & & & \\
$\mathrm{E}(1)-\mathrm{Pt}(1)$ & $2.336(2)$ & $2.4558(16) 2.324(4)$ & $2.449(3)$ \\
$\mathrm{E}(9)-\mathrm{Pt}(1)$ & $2.323(3)$ & $2.4356(16) 2.324(5)$ & $2.438(3)$ \\
$\mathrm{P}(1)-\mathrm{Pt}(1)$ & $2.301(2)$ & $2.304(4)$ & $2.258(5)$ & $2.279(4)$ \\
$\mathrm{P}(2)-\mathrm{Pt}(1)$ & $2.295(2)$ & $2.294(4)$ & $2.267(4)$ & $2.277(5)$ \\
Metal geometry-bond angles & & & & \\
$\mathrm{E}(1)-\mathrm{Pt}(1)-\mathrm{E}(9)$ & $89.07(8)$ & $89.27(6)$ & $89.61(15)$ & $88.78(6)$ \\
$\mathrm{E}(1)-\mathrm{Pt}(1)-\mathrm{P}(1)$ & $86.53(8)$ & $86.47(10)$ & $84.53(15)$ & $86.60(11)$ \\
$\mathrm{P}(1)-\mathrm{Pt}(1)-\mathrm{P}(2)$ & $97.51(8)$ & $97.68(13)$ & $100.84(15) 100.45(14)$ \\
$\mathrm{E}(9)-\mathrm{Pt}(1)-\mathrm{P}(2)$ & $87.54(8)$ & $87.56(10)$ & $85.47(14)$ & $84.67(11)$ \\
$\mathrm{E}(1)-\mathrm{Pt}(1)-\mathrm{P}(2)$ & $172.20(9)$ & $170.63(12) 173.00(16) 171.08(10)$ \\
$\mathrm{E}(9)-\mathrm{Pt}(1)-\mathrm{P}(1)$ & $172.79(8)$ & $171.95(11) 171.87(13) 173.09(12)$ \\
Metal geometry-distortion & & & & \\
$\mathrm{E}_{2} \mathrm{Pt}-\mathrm{P}(1)$ distance & $0.229(1)$ & $0.274(1)$ & $0.220(1)$ & $-0.204(1)$ \\
$\mathrm{E}_{2} \mathrm{Pt}-\mathrm{P}(2)$ distance & $-0.281(1)$ & $-0.351(1)$ & $-0.196(1)$ & $0.240(1)$ \\
Envelope geometry & & & & \\
$\mathrm{E}_{2} \mathrm{C}_{3}-\mathrm{Pt}$ angle & $135.92(1)$ & $139.16(1)$ & $134.44(1)$ & $133.77(1)$ \\
$\mathrm{E}_{2} \mathrm{C}_{3}-\mathrm{Pt}$ distance & $1.152(1)$ & $1.137(1)$ & $1.175(1)$ & $1.259(1)$ \\
\hline
\end{tabular}

Treatment of the dilithium salts of $\mathbf{L 1}$ and $\mathbf{L 2}$ with cis$\left[\mathrm{PtCl}_{2}\left(\mathrm{PPh}_{3}\right)_{2}\right]$ afforded two isomorphous monomeric, mononuclear four coordinate platinum(II) complexes $[\mathrm{Pt}(5,6-$ AcenapE $\left.\left.\mathrm{E}_{2}\right)\left(\mathrm{Ph}_{3}\right)_{2}\right](\mathbf{1} \mathrm{E}=\mathrm{S} ; 2 \mathrm{E}=\mathrm{Se}$; Figure 3). Similarly, the corresponding reactions with cis- $\left[\mathrm{PtCl}_{2}\left(\mathrm{PPhMe}_{2}\right)_{2}\right]$ generated a pair of equivalent isomorphous platinum(II) complexes $[\mathrm{Pt}(5,6-$ AcenapE $\left.\left.\mathrm{E}_{2}\right)\left(\mathrm{PhMe}_{2}\right)_{2}\right](5 \mathrm{E}=\mathrm{S} ; 6 \mathrm{E}=\mathrm{Se}$; Figure 4). In each case, the symmetrical bidentate dichalcogen ligand binds via both $\mathrm{E}$ atoms forming a chelate ring with the central metal. The $\mathrm{PtE}_{2} \mathrm{C}_{3}$ six-membered rings are hinged about the $\mathrm{E} \cdots \mathrm{E}$ vector and adopt a twisted envelope type conformation (Figure 5); E(1), E(9), $C(1), C(10)$ and $C(9)$ are essentially coplanar with the platinum atom lying in the peri-gap, displaced 1.15-1.26 $\AA$ above the $\mathrm{E}_{2} \mathrm{C}_{3}$ plane, with the $\mathrm{E}(1)-\mathrm{Pt}(1)-\mathrm{E}(9)$ plane inclined by $134-139^{\circ}$.

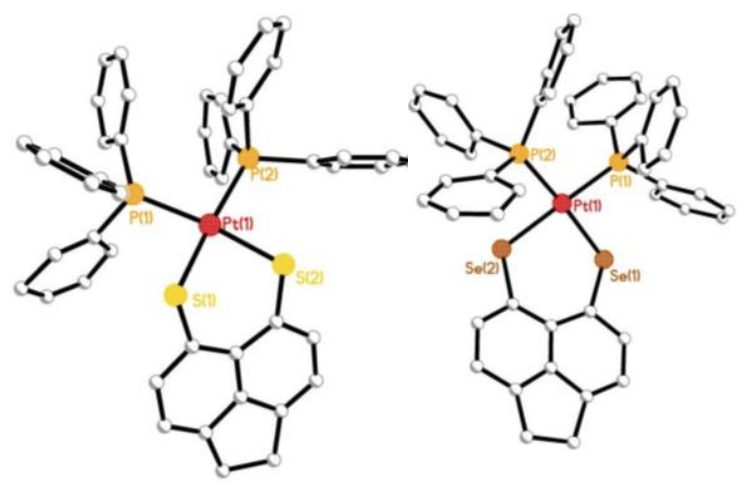

Figure 3. The molecular structures of complexes $\mathbf{1}$ and $\mathbf{2}$ formed from cis-[ $\left[\mathrm{PtCl}_{2}\left(\mathrm{PPh}_{3}\right)_{2}\right]$ and bearing chalcogen ligands $\mathbf{L 1}$ and $\mathbf{L 2}(\mathrm{H}$ atoms omitted for clarity).

As a consequence of the ligand geometry, the two phosphine moieties retain a cis-orientation around platinum and complete a distorted square planar geometry. The $\mathrm{P}(1)-\mathrm{Pt}(1)-\mathrm{P}(2)$ angles for complexes $1\left(97.51(8)^{\circ}\right)$ and $2\left(97.68(13)^{\circ}\right)$ bearing the $\mathrm{PPh}_{3}$ moiety show considerable deviation from the ideal $90^{\circ}$ in accord with previously published examples. Counterintuitively, even larger angles are exhibited by complexes $5\left(100.84(15)^{\circ}\right)$ and $\mathbf{6}$ $\left(100.45(14)^{\circ}\right)$, despite incorporating the less sterically hindered $\mathrm{PPhMe}_{2}$ functionality, associated with a smaller Tolman cone angle $\left(\mathrm{PPhMe}_{2} 1^{136^{\circ}}\right.$ cf. $\mathrm{PPh}_{3} 1^{\left.145^{\circ}\right) .[30]}$ In contrast, corresponding $\mathrm{E}(1)-\mathrm{Pt}(1)-\mathrm{E}(9)$ angles are consistent in all four complexes with angles in the range $88.78(6)-89.61(15)^{\circ}$. The cis $\mathrm{E}(1)-\mathrm{Pt}(1)-\mathrm{P}(1), \mathrm{E}(9)-\mathrm{Pt}(1)-\mathrm{P}(2)$ 84.53(15)-87.56(10) ${ }^{\circ}$ and trans $\mathrm{E}(1)-\mathrm{Pt}(1)-\mathrm{P}(2), \mathrm{E}(9)-\mathrm{Pt}(1)-\mathrm{P}(1)$ 170.63(12)-173.09(12) ${ }^{\circ}$ angles also fall within accepted ranges for similar platinum complexes[12,27] but highlight the distortion of the square planar environment at the central platinum core. Pt-S (2.323(3)-

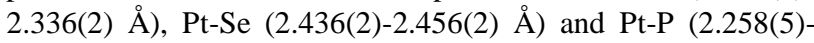
2.304(4) $\AA$ ) bond lengths correspond to distances seen in previous naphthalene complexes.[12,27] In addition to the inplane deviations, further distortion is observed in all four complexes, with out-of-plane displacement of the coordinating $\mathrm{E}$ and $\mathrm{P}$ atoms reducing the planarity of the platinum primary coordination sphere. This can be compared by monitoring the location of the $\mathrm{P}$ atoms with respect to the mean E-Pt-E plane (Figure 6). In each case $\mathrm{E}(1), \operatorname{Pt}(1)$ and $\mathrm{E}(9)$ are essentially coplanar with the $\mathrm{P}$ atoms displaced to opposite sides of this plane by 0.2-0.4 $\AA$ (Figure 6). The C-E-Pt bond angles are found to decrease from $\mathrm{PPh}_{3}$ to $\mathrm{PPhMe}_{2}$, with average angles for $\mathbf{1}$ and $2111^{\circ}$ compared with $109^{\circ}$ in $\mathbf{5}$ and $\mathbf{6}$. The reduction in the C-E-Pt angle is consistent with the smaller functionality on the phosphorus, allowing platinum to lie closer to the acenaphthene framework.

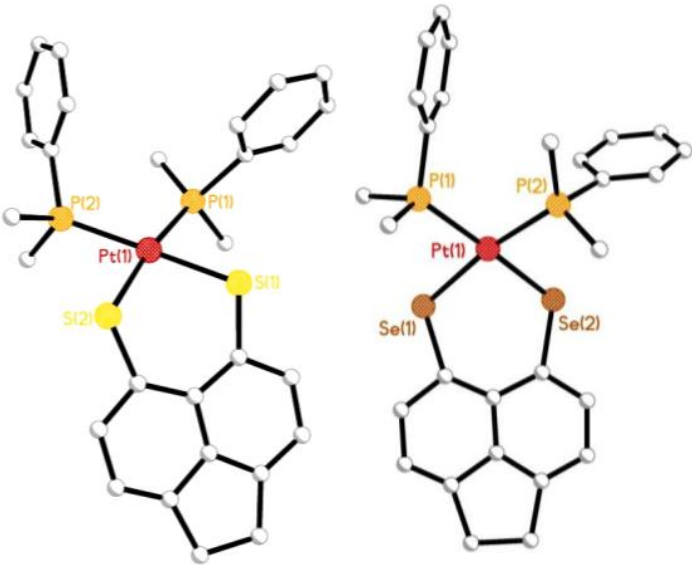

Figure 4. The molecular structures of complexes $\mathbf{5}$ and $\mathbf{6}$ formed from cis- $\left[\mathrm{PtCl}_{2}\left(\mathrm{PPhMe}_{2}\right)_{2}\right]$ ( $\mathrm{H}$ atoms omitted for clarity).

The arrangement of substituents in trivalent phosphorus ligands is dictated by steric effects; R-P-R angles are commonly less than $109.5^{\circ}$, approaching an ideal tetrahedral geometry as bulky groups are added.[30] In complexes 1, 2, 5 and 6 the nature of the AcenapE $E_{2}$ ligand has no apparent effect on the conformation of the phosphorus moiety, with comparable R-P-R angles for $\mathbf{1}$ (av. 103.5 ) and $\mathbf{2}$ (av. 103.7 ), 5 (av. $102.3^{\circ}$ ) and 6 (av. 102.8) respectively. Whilst the average of the $\mathrm{C}_{\mathrm{Ph}}-\mathrm{P}-\mathrm{C}_{\mathrm{Ph}}$ angles in $\mathbf{1}$ and $\mathbf{2}$ (av. $104^{\circ}$ ) is closer to that of a standard tetrahedral arrangement (as expected for larger substituents),[30] the angles range between $97.6(4)^{\circ}$ and an unusually large $111.8(4)^{\circ}\left(c f . \mathbf{5 / 6} 99.6(6)-105.8(8)^{\circ}\right)$. As might be expected from the larger steric influence of the $\mathrm{PPh}_{3}$ group compared with $\mathrm{PPhMe}_{2}$, longer Pt-P bonds are observed in $\mathbf{1}$ and 2 (av. $2.30 \AA$ ) compared with 5 and $\mathbf{6}(2.27 \AA)$. Whilst 
steric effects dominate the configuration of substituents around phosphorus, weak interactions between the functional groups of neighbouring phosphorus atoms can influence the structure of the complex. In complexes $\mathbf{1}$ and $\mathbf{2}$, two neighbouring phenyl rings attached to independent $\mathrm{P}$ atoms adopt a parallel alignment similar to the face-to-face offset arrangement (Figure 7),[31] with non-bonded distances between interacting centroids $(\operatorname{cg}(25-30) \cdots \operatorname{cg}(31-36): 13.765(1) \AA ; 2$ 3.764(1) $\mathrm{A})$ within the range for typical $\pi \cdots \pi$ stacking (3.3-3.8 $\AA$ ).[31] Similarly, complexes 5 and 6 exhibit weak $\mathrm{CH} \cdots \pi$ type non-conventional hydrogen bond interactions[32] between neighbouring methyl and phenyl moieties of adjacent phosphorus groups (5 C(14)-

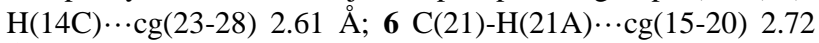
$\AA$ A; Figure 8).

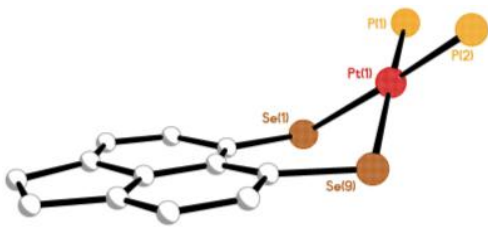

Figure 5. The open envelope configuration of the 6-membered chelate ring, formed from bidentate Se coordination of $\mathbf{L} \mathbf{2}$ in complex $\mathbf{6}$ (phenyl and methyl groups and $\mathrm{H}$ atoms omitted for clarity).

Unsurprisingly, cleavage of the short E-E covalent bond and subsequent coordination to platinum in complexes 1, 2, 5 and $\mathbf{6}$ causes steric strain to accumulate between the bulky chalcogen atoms. Repulsive interactions between the two perifunctionalities, resulting from sub-van der Waals contacts, leads to deformation of the carbon framework via in-plane and out-ofplane distortions and buckling of the aromatic ring system (angular strain), ultimately disrupting the relaxed geometry previously achieved by the free ligands. As a consequence of the square planar metal geometry, the exocyclic $\mathrm{E}-\mathrm{C}_{\text {Acenap }}$ bonds now diverge, resulting in large positive splay angles in the range $23-26^{\circ}$ and extended non-bonded $\mathrm{E} \cdots \mathrm{E}$ distances, greater than 1 $\AA$ longer than the E-E distances in the Acenap $\mathrm{E}_{2}$ ligands (1

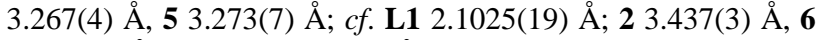

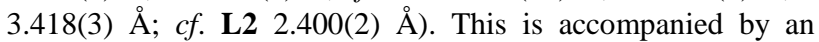
increase in the out-of-plane displacement of the peri-atoms (0$0.2 \AA ; c f$. L1/L2 $0-0.05 \AA$ ) and a reduction in the planarity of the carbon skeleton $\left(\mathrm{C}-\mathrm{C}-\mathrm{C}-\mathrm{C}\right.$ torsion angles $0.1-7^{\circ} ; c f$. L1/L2 $0-0.1^{\circ}$ ). As can be seen from the magnitude of the E $\cdots \mathrm{E}$ periseparations, the subtle change of the phosphorus functionality from $\mathrm{PPh}_{3}$ to $\mathrm{PPhMe}_{2}$ has only a minor effect on the geometry of the acenaphthene fragment in these complexes. The most notable difference is observed within the bay-region, with marginally larger splay angles exhibited by complexes $\mathbf{2}$ and $\mathbf{6}$ $\left(\mathrm{PPhMe}_{2}\right)$, increasing by $\sim 1^{\circ}$ compared with 1 and $5\left(\mathrm{PPh}_{3}\right)$. Naturally, selenium analogues $\mathbf{2}$ and $\mathbf{6}$ exhibit greater molecular distortion within the acenaphthene fragment and longer peri $\mathrm{E} \cdots \mathrm{E}$ distances compared with sulfur equivalents $\mathbf{1}$ and $\mathbf{5}$, in line with the greater bulk of the interacting atoms.
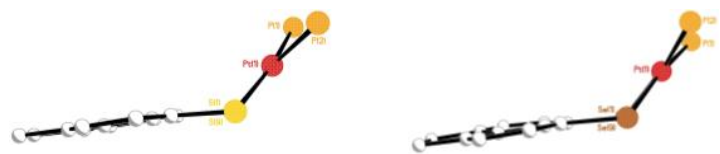

Figure 6. Out-of-plane distortion of the square planar geometry in $\mathbf{5}$ and 6; displacement of the $\mathrm{P}$ atoms from the mean E-Pt-E plane (phenyl and methyl groups and $\mathrm{H}$ atoms omitted for clarity).
During an earlier study of platinum bisphosphine complexes bearing a range of dichalcogen derivatised naphthalene, acenaphthene and phenanthrene ligands, we prepared $[\operatorname{Pt}(1,8-$ $\left.\left.\mathrm{NapSe}_{2}\right)\left(\mathrm{PPh}_{3}\right)_{2}\right] \mathbf{N 2}$, the naphthalene analogue of complex 2.[12] Although both compounds adopt comparable structures in the solid, introduction of the ethane linkage at the 1,2positions of complex $\mathbf{2}$ has a noticeable influence on the phosphorus geometry and degree of molecular distortion in the organic backbone compared with $\mathbf{N 2}$. The greatest discrepancy between the two compounds is found in the planarity of the organic frameworks, with significantly less buckling observed within the acenaphthene ring system of $\mathbf{2}$ (maximum C-C-C-C central ring torsion angles $\left.\sim 2^{\circ} ; c f . \mathbf{N 2} \sim 1-5^{\circ}\right)$. [12] Associated with this is a reduction in out-of-plane distortion, where one of the selenium atoms in $\mathbf{2}$ essentially resides on the mean acenaphthene plane, with the second atom displaced by only $\sim 0.1 \AA$ ( $c f$. N2 both Se atoms displaced $\sim 0.2 \AA$ from the mean naphthalene plane).[12] The natural splay of the exocyclic bonds in acenaphthene compounds compared with naphthalene equivalents accounts for the larger in-plane distortion observed in 2 (splay angle: $25.7^{\circ} ; c f$. $\mathbf{N 2 ~} 23.8^{\circ}\left[20.0^{\circ}\right]$ ), resulting in a minor lengthening of the Se-.Se separation (2 3.437(3) A; N2 3.37(1) ̊ [3.36(1) ̊]]).[12]

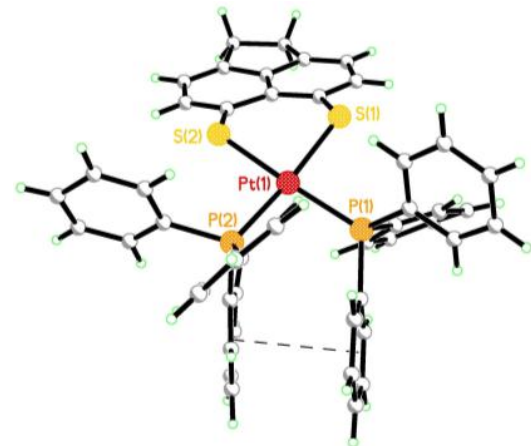

Figure 7. Overlapping phenyl rings in the isomorphous complexes 1 (shown) and $\mathbf{2}$ align with a weak face-to-face offset arrangement and interact via weak $\pi \cdots \pi$ stacking.
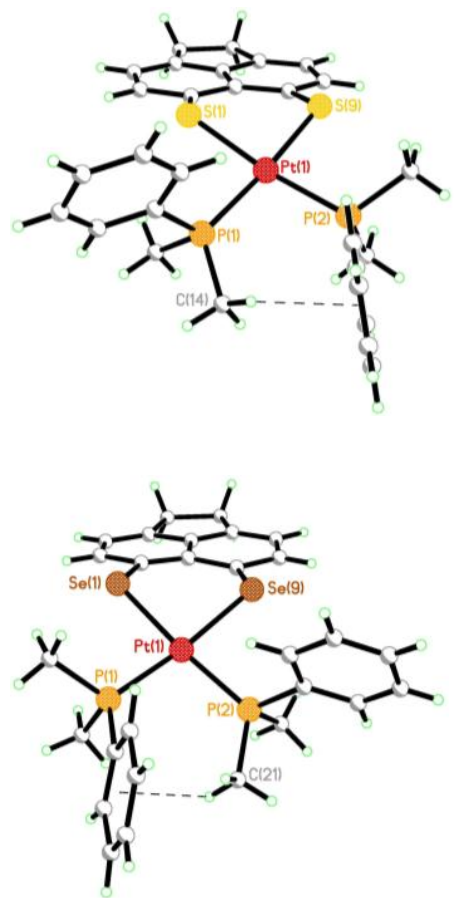

Figure 8. Adjacent phenyl and methyl moieties interact in $\mathbf{5}$ and $\mathbf{6}$ via weak non-conventional $\mathrm{CH} \cdots \pi$ type interactions. 
Table 4. Crystallographic data for $L 1, L 2,1,2,5,6$

\begin{tabular}{|c|c|c|c|c|c|c|}
\hline Compound & $\mathrm{L} 1$ & $\mathrm{~L} 2$ & 1 & 2 & 5 & 6 \\
\hline Empirical Formula & $\mathrm{C}_{12} \mathrm{H}_{8} \mathrm{~S}_{2}$ & $\mathrm{C}_{12} \mathrm{H}_{8} \mathrm{Se}_{2}$ & $\mathrm{C}_{48} \mathrm{H}_{38} \mathrm{P}_{2} \mathrm{PtS}_{2}$ & $\mathrm{C}_{48} \mathrm{H}_{38} \mathrm{P}_{2} \mathrm{PtSe}_{2}$ & $\mathrm{C}_{28} \mathrm{H}_{30} \mathrm{P}_{2} \mathrm{PtS}_{2}$ & $\mathrm{C}_{28} \mathrm{H}_{30} \mathrm{P}_{2} \mathrm{PtSe}_{2}$ \\
\hline Formula Weight & 216.32 & 310.12 & 935.99 & 1029.79 & 687.70 & 781.50 \\
\hline Temperature $\left({ }^{\circ} \mathrm{C}\right)$ & $-148(1)$ & $-148(1)$ & $-180(1)$ & $-180(1)$ & $-148(1)$ & $-148(1)$ \\
\hline Crystal Colour, Habit & orange, platelet & green, platelet & orange, prism & orange, prism & orange, platelet & orange, plate \\
\hline \multirow{2}{*}{ Crystal Dimensions $\left(\mathrm{mm}^{3}\right)$} & $0.09 \times 0.09 \times$ & $0.30 \times 0.30 \mathrm{X}$ & $0.20 \times 0.20 \mathrm{X}$ & $0.10 \times 0.10 \mathrm{X}$ & $0.17 \times 0.08 \times$ & $0.15 \times 0.15 \times$ \\
\hline & 0.03 & 0.02 & 0.20 & 0.03 & 0.02 & 0.09 \\
\hline Crystal System & monoclinic & monoclinic & monoclinic & monoclinic & triclinic & triclinic \\
\hline \multirow[t]{6}{*}{ Lattice Parameters } & $\mathrm{a}=13.871(8) \AA$ & $\mathrm{a}=7.359(5) \AA$ & $a=9.769(3) \AA$ & $a=9.797(4) \AA$ & $\mathrm{a}=9.978(3) \AA$ & $a=10.111(7) \AA$ \\
\hline & $\mathrm{b}=4.952(3) \AA$ & $\mathrm{b}=21.383(14) \AA$ & $\mathrm{b}=17.571(5) \AA$ & $\mathrm{b}=17.656(5) \AA$ & $\mathrm{b}=11.416(4) \AA$ & $\mathrm{b}=11.637(11) \AA$ \\
\hline & $c=14.633(7) \AA$ & $c=12.304(9) \AA$ & $\mathrm{c}=22.605(6) \AA$ & $\mathrm{c}=22.821(8) \AA$ & $\mathrm{c}=11.731(4) \AA$ & $c=11.678(10) \AA$ \\
\hline & - & - & - & - & $\alpha=106.918(9)^{\circ}$ & $\alpha=106.30(3)^{\circ}$ \\
\hline & $\beta=116.097(12)^{\circ}$ & $\beta=99.016(19)^{\circ}$ & $\beta=102.379(7)^{\circ}$ & $\beta=101.690(8)^{\circ}$ & $\beta=92.914(10)^{\circ}$ & $\beta=94.62(2)^{\circ}$ \\
\hline & - & - & - & - & $\gamma=95.035(9)^{\circ}$ & $\gamma=93.48(3)^{\circ}$ \\
\hline Volume $\left(\AA^{3}\right)$ & $\mathrm{V}=902.7(8)$ & $\mathrm{V}=1912(2)$ & $\mathrm{V}=3790(2)$ & $V=3865(3)$ & $V=1269.4(7)$ & $\mathrm{V}=1310(2)$ \\
\hline Space Group & $\mathrm{P} 2_{1} / \mathrm{n}$ & $\mathrm{P} 2{ }_{1} / \mathrm{n}$ & $\mathrm{P} 2{ }_{1} / \mathrm{n}$ & $\mathrm{P} 2{ }_{1} / \mathrm{n}$ & $\mathrm{P}-1$ & $\mathrm{P}-1$ \\
\hline $\mathrm{Z}$ value & 4 & 8 & 4 & 4 & 2 & 2 \\
\hline Dcalc $\left(\mathrm{g} / \mathrm{cm}^{3}\right)$ & 1.592 & 2.154 & 1.640 & 1.769 & 1.799 & 1.982 \\
\hline F000 & 448 & 1184 & 1864 & 2008 & 676 & 748 \\
\hline $\mathrm{m}(\mathrm{MoKa})\left(\mathrm{cm}^{-1}\right)$ & 5.346 & 76.842 & 39.177 & 56.169 & 58.114 & 82.538 \\
\hline No. of Reflections Measured & 7383 & 15458 & 23502 & 24021 & 8862 & 11373 \\
\hline Rint & 0.0660 & 0.1143 & 0.1206 & 0.1944 & 0.0909 & 0.0604 \\
\hline Min and Max Transmissions & $0.765-0.984$ & $0.442-0.858$ & $0.201-0.457$ & $0.306-0.845$ & - & $0.271-0.476$ \\
\hline $\begin{array}{l}\text { Observed Reflection (No. } \\
\text { Variables ) }\end{array}$ & $2055(127)$ & $3850(253)$ & $6898(466)$ & $7007(459)$ & $4268(298)$ & $5707(298)$ \\
\hline Reflection/Parameter Ratio & 16.18 & 15.22 & 14.80 & 15.27 & 14.32 & 19.15 \\
\hline Residuals: $\mathrm{R}_{1}(\mathrm{I}>2.00 \mathrm{~s}(\mathrm{I}))$ & 0.0904 & 0.0981 & 0.0701 & 0.0898 & 0.0771 & 0.0611 \\
\hline Residuals: R (All reflections) & 0.1297 & 0.1337 & 0.0884 & 0.1314 & 0.0918 & 0.0911 \\
\hline Residuals: $w_{2}$ (All reflections) & 0.2913 & 0.2569 & 0.1938 & 0.2369 & 0.1529 & 0.2645 \\
\hline Goodness of Fit Indicator & 1.133 & 1.240 & 1.069 & 1.052 & 1.193 & 1.039 \\
\hline $\begin{array}{l}\text { Maximum peak in Final Diff. } \\
\text { Map }\end{array}$ & $1.63 \mathrm{e}^{-} / \AA^{3}$ & $1.40 \mathrm{e}^{-} / \AA^{3}$ & $2.06 \mathrm{e}^{-} / \AA^{3}$ & $1.83 \mathrm{e}^{-/} \AA^{3}$ & $1.57 \mathrm{e}^{-} / \AA^{3}$ & $2.28 \mathrm{e}^{-} / \AA^{3}$ \\
\hline $\begin{array}{l}\text { Minimum peak in Final Diff. } \\
\text { Map }\end{array}$ & $-1.01 \mathrm{e}^{-} / \AA^{3}$ & $-1.85 \mathrm{e}^{-} / \AA^{3}$ & $-3.40 \mathrm{e}^{-} / \AA^{3}$ & $-2.24 \mathrm{e}^{-} / \AA^{3}$ & $-2.97 \mathrm{e}^{-} / \AA^{3}$ & $-4.62 \mathrm{e}^{-} / \AA^{3}$ \\
\hline
\end{tabular}

Whilst the in-plane Se-Pt-Se $\left(86-89^{\circ}\right)$, Se-Pt-P $\left(86-89^{\circ}\right)$ and P-Pt-P (98-99 $)$ angles are comparable in both complexes, outof-plane displacement (metal geometry) of the two $\mathrm{P}$ atoms with respect to the $\mathrm{Se}_{2} \mathrm{Pt}$ plane is marginally greater in the naphthalene analogue ( 0.4-0.5 $\AA$; $c f .20 .2-0.3 \AA)$.[12] As might be expected, the $\mathrm{PPh}_{3}$ groups in 2 adopt a similar configuration to those found in the naphthalene analogue, with comparable R-P-R angles for the two complexes $\left(98-113^{\circ}\right)$. Interestingly, whilst neighbouring phenyl rings of complex $\mathbf{N 2}$ overlap, the distance between the two interacting centroids (4.167(1) $\AA$ [4.166(1) $\AA$ ] ) is outside the range for standard $\pi \cdots \pi$ stacking to occur (3.3-3.8 $\mathrm{A})$.[12,31]

\section{Conclusions}

The work presented in this paper builds on our previous studies of platinum bisphosphine complexes bearing dichalcogenide based ligands.[12] Herein we present the synthesis of a related series of platinum complexes 1-6 incorporating 5,6-dihydroacenaphtho[5,6-cd]-1,2dichalcogenoles $\left[\right.$ Acenap $\left._{2}\right] \mathbf{L 1}(\mathrm{E}=\mathrm{S})$ and $\mathbf{L 2}(\mathrm{E}=\mathrm{Se})$ and cis- $\left[\mathrm{PtCl}_{2}\left(\mathrm{PR}_{3}\right)_{2}\right]\left(\mathrm{R}_{3}=\mathrm{Ph}_{3}, \mathrm{Ph}_{2} \mathrm{Me}, \mathrm{PhMe}_{2}\right)$. For their synthesis, the appropriate disulfide or diselenide species was treated with super hydride $\left[\mathrm{LiBEt}_{3} \mathrm{H}\right]$ affording the dilithium salt by in situ reduction of the $\mathrm{AcenapE}_{2}$ E-E bond. Further reaction, via metathetical addition to the cis-platinum precursor afforded the respective platinum(II) complex $\left[\mathrm{Pt}\left(5,6-\mathrm{AcenapE}_{2}\right)\left(\mathrm{PR}_{3}\right)_{2}\right]\left(\mathrm{R}_{3}=\right.$ $\mathrm{Ph}_{3}: \mathrm{E}=\mathrm{S} \mathrm{1}$, Se 2; $\mathrm{R}_{3}=\mathrm{Ph}_{2} \mathrm{Me}: \mathrm{E}=\mathrm{S} \mathrm{3}$, Se 4; $\mathrm{R}_{3}=\mathrm{PhMe}_{2}: \mathrm{E}=$ $\mathrm{S} \mathrm{5}$, Se 6). Sulfur complexes $\mathbf{1}, \mathbf{3}$ and $\mathbf{5}$ display expected single resonances with platinum satellites in their respective ${ }^{31} \mathrm{P}\left\{{ }^{1} \mathrm{H}\right\}$ NMR spectra, moving to lower chemical shifts and with decreasing ${ }^{1} J\left({ }^{31} \mathrm{P},{ }^{195} \mathrm{Pt}\right)$ coupling constants as the alkyl group on phosphorus is varied from $\mathrm{R}_{3}=\mathrm{Ph}_{3}$ to $\mathrm{R}_{3}=\mathrm{PhMe}_{2}$. The inclusion of the low abundant ${ }^{77} \mathrm{Se}$ NMR active isotope in complexes 2,4 and 6 provides extra complexity to their respective ${ }^{31} \mathrm{P}\left\{{ }^{1} \mathrm{H}\right\}$ NMR spectra. These can be analysed as $\mathrm{AA}^{\prime} \mathrm{X}$ if the satellites for ${ }^{31} \mathrm{P} /{ }^{77} \mathrm{Se}-{ }^{195} \mathrm{Pt}$ coupling are disregarded.[26] The AA nuclei correspond to the two ${ }^{31} \mathrm{P}$ atoms which align with either a cis or trans configuration with respect to the $\mathrm{X}$-nucleus in the spin system (the ${ }^{77} \mathrm{Se}$ NMR active isotope), making them magnetically inequivalent. The ${ }^{31} \mathrm{P}\left\{{ }^{1} \mathrm{H}\right\}$ NMR spectra of complex 6 displays the expected pattern for the AA nuclei of an AA'X spin system;[26] in addition to the established single resonance accompanied by satellites for ${ }^{1} J\left({ }^{31} \mathrm{P},{ }^{195} \mathrm{Pt}\right)$ coupling, two sets of ${ }^{77} \mathrm{Se}$ satellites are clearly present, with ${ }^{2} J\left({ }^{31} \mathrm{P},{ }^{77} \mathrm{Se}\right)$ values of $47 \mathrm{~Hz}$ and $56 \mathrm{~Hz}$ corresponding to the cis and trans couplings. ${ }^{1} J\left({ }^{31} \mathrm{P}_{\mathrm{A}}{ }^{31} \mathrm{P}_{\mathrm{A}}\right)$ coupling constants are notoriously small for AA'X spin systems and were not observed in the spectra of 2, 4 and 6.[27]

X-ray structures determined for 1, 2, 5 and $\mathbf{6}$ were analysed by platinum metal geometry, peri-atom displacement, splay angle magnitude, acenaphthene ring torsion angles and $\mathrm{E} \cdots \mathrm{E}$ 
interactions and compared to the structures of the free ligands $\mathbf{L 1}$ and L2. In each complex the symmetrical bidentate AcenapE $_{2}$ ligand coordinates to platinum to form a sixmembered chelate ring which adopts a twisted envelope type motif. The two phosphine ligands retain a cis-orientation around platinum which lies at the centre of a distorted square-planar environment. Naturally, coordination to platinum and cleavage of the E-E bond results in a dramatic increase in molecular distortion in the acenaphthene component of 1, 2, 5 and 6 compared with free ligands $\mathbf{L 1}$ and L2. Divergence of the exocyclic bonds results in large positive splay angles in the range $23-26^{\circ}$ and extended non-bonded $\mathrm{E} \cdots \mathrm{E}$ distances, $1 \AA$ longer than the E-E distances in the AcenapE $E_{2}$ ligands. The nature of the $A_{c e n a p E_{2}}$ ligand has no apparent effect on the conformation of the phosphorus moiety, with comparable R-P-R angles for 1 and 2, 5 and $\mathbf{6}$ respectively. Similarly, the subtle change of the phosphorus functionality from $\mathrm{PPh}_{3}$ to $\mathrm{PPhMe}_{2}$ has only a minor effect on the geometry of the acenaphthene fragment in these complexes.

\section{Experimental Section}

All experiments were carried out under an oxygen- and moisture-free nitrogen atmosphere using standard Schlenk techniques and glassware. Reagents were obtained from commercial sources and used as received. Dry solvents were collected from a MBraun solvent system. Elemental analyses were performed by Stephen Boyer at the London Metropolitan University. Infra-red spectra were recorded as $\mathrm{KBr}$ discs in the range 4000-300 $\mathrm{cm}^{-1}$ on a Perkin-Elmer System 2000 Fourier transform spectrometer. ${ }^{1} \mathrm{H}$ and ${ }^{13} \mathrm{C}$ NMR spectra were recorded on a Jeol GSX $270 \mathrm{MHz}$ spectrometer with $\delta(\mathrm{H})$ and $\delta(\mathrm{C})$ referenced to external tetramethylsilane. ${ }^{31} \mathrm{P}$ and ${ }^{77} \mathrm{Se}$ NMR spectra were recorded on a Jeol GSX $270 \mathrm{MHz}$ spectrometer with $\delta(\mathrm{P})$ and $\delta(\mathrm{Se})$ referenced to external phosphoric acid and dimethylselenide respectively. Assignments of ${ }^{13} \mathrm{C}$ and ${ }^{1} \mathrm{H}$ NMR spectra were made with the help of $\mathrm{H}-\mathrm{H}$ COSY and HSQC experiments. All measurements were performed at $25^{\circ} \mathrm{C}$. All values reported for NMR spectroscopy are in parts per million (ppm). Coupling constants $(J)$ are given in Hertz $(\mathrm{Hz})$. Mass spectrometry was performed by the University of St. Andrews Mass Spectrometry Service; Electrospray Mass Spectrometry (ESMS) was carried out on a Micromass LCT orthogonal accelerator time of flight mass spectrometer. Platinum metal precursors cis- $\left[\mathrm{PtCl}_{2}\left(\mathrm{PR}_{3}\right)\right]\left(\mathrm{R}_{3}=\mathrm{Ph}_{3}, \mathrm{Ph}_{2} \mathrm{Me}, \mathrm{PhMe}_{2}\right)$ were prepared following standard literature procedures.[12]

\section{5,6-dihydroacenaphtho[5,6-cd][1,2]dithiole $\left[\right.$ AcenapS $\left._{2}\right]$ (L1): The} title compound was prepared by a method previously described.[23] To a stirred solution of 5,6-dibromoacenaphthene (5.0 g, $16.03 \mathrm{mmol})$ and TMEDA ( $4.8 \mathrm{~mL}, 16.03 \mathrm{mmol})$ in diethyl ether $(200 \mathrm{~mL})$ was slowly added a $2.5 \mathrm{M}$ hexane solution of $n$-butyllithium $(6.4 \mathrm{~mL}, 16.03 \mathrm{mmol})$ at $-78^{\circ} \mathrm{C}$. After the mixture was stirred for $15 \mathrm{~min}$ at this temperature, sulfur flowers $(0.51 \mathrm{~g}, 16.03 \mathrm{mmol})$ were added and stirring was continued at $-40{ }^{\circ} \mathrm{C}$ for $2 \mathrm{~h}$. The mixture was cooled again to $-78^{\circ} \mathrm{C}$, after which a $2.5 \mathrm{M}$ hexane solution of $n$-butyllithium $(6.4 \mathrm{~mL}, 16.03$ mmol) was added and the reaction mixture stirred at this temperature for $15 \mathrm{~min}$. Additional sulfur $(0.51 \mathrm{~g}, 16.03 \mathrm{mmol})$ was added and the reaction mixture stirred for a further $2 \mathrm{~h}$ at $-40{ }^{\circ} \mathrm{C}$. The mixture was then quenched with acetic acid $(2 \mathrm{~mL})$ and exposed to an air stream overnight for oxidation. The resulting solution was concentrated under reduced pressure and after water was added, the mixture was extracted with dichloromethane. The extract was dried over anhydrous magnesium sulfate. After the solvent was removed in vacuo, the residue was purified by column chromatography on silica gel (hexane). An analytically pure sample was obtained by recrystallization from hexane to give the desired product as orange crystals $(0.70 \mathrm{~g}, 20 \%)$; mp 178$182{ }^{\circ} \mathrm{C}$; (Found: C, 66.5; H, 3.8. Anal. Calc. for $\mathrm{C}_{12} \mathrm{H}_{8} \mathrm{~S}_{2}$ : C, 66.6; $\mathrm{H}$, $3.7 \%) ; \delta_{\mathrm{H}}\left(270 \mathrm{MHz}, \mathrm{CDCl}_{3}, 25^{\circ} \mathrm{C}, \mathrm{Me}_{4} \mathrm{Si}\right) 7.06\left(1 \mathrm{H}, \mathrm{d},{ }^{3} J_{\mathrm{HH}} 7.5\right.$, Acenap 4,7-H), 7.02(1 H, d, ${ }^{3} J_{\mathrm{HH}}$ 7.2, Acenap 3,8-H), 3.29 (4 H, s, 2 x $\left.\mathrm{CH}_{2}\right) ; \delta_{\mathrm{C}}\left(67.9 \mathrm{MHz} ; \mathrm{CDCl}_{3} ; 25^{\circ} \mathrm{C} ; \mathrm{Me}_{4} \mathrm{Si}\right) 121.1(\mathrm{~s}), 116.9(\mathrm{~s})$, $30.7\left(\mathrm{~s}, \mathrm{CH}_{2}\right) ; \mathrm{m} / z\left(\mathrm{ES}^{+}\right) 215.87\left([\mathrm{M}]^{+}, 100 \%\right)$.

5,6-dihydroacenaphtho[5,6-cd] $[1,2]$ diselenole [AcenapSe 2 (L2): The title compound was prepared by a method previously described.[23] To a stirred solution of 5,6-dibromoacenaphthene $(2.62 \mathrm{~g}, 8.40 \mathrm{mmol})$ and TMEDA (2.5 mL, $16.1 \mathrm{mmol})$ in diethyl ether $(200 \mathrm{~mL})$ was slowly added a $2.5 \mathrm{M}$ hexane solution of $n$-butyllithium $(3.4 \mathrm{~mL}, 8.40 \mathrm{mmol}$ ) at $-78^{\circ} \mathrm{C}$. After the mixture was stirred for $15 \mathrm{~min}$ at this temperature, selenium powder $(0.66 \mathrm{~g}, 8.40 \mathrm{mmol})$ was added and stirring was continued at $-40{ }^{\circ} \mathrm{C}$ for $2 \mathrm{~h}$. The mixture was cooled again to $-78^{\circ} \mathrm{C}$, after which a $2.5 \mathrm{M}$ hexane solution of $n$-butyllithium $(3.4 \mathrm{~mL}, 8.40$ $\mathrm{mmol})$ was added and the reaction mixture stirred at this temperature for $15 \mathrm{~min}$. Additional selenium powder $(0.66 \mathrm{~g}, 8.40 \mathrm{mmol})$ was added and the reaction mixture stirred for a further $2 \mathrm{~h}$ at $-40{ }^{\circ} \mathrm{C}$. The mixture was then quenched with acetic acid $(2 \mathrm{~mL})$ and exposed to an air stream overnight for oxidation. The resulting solution was concentrated under reduced pressure and after water was added, the mixture was extracted with dichloromethane. The extract was dried over anhydrous magnesium sulfate. After the solvent was removed in vacuo, the residue was purified by column chromatography on silica gel (hexane/dichloromethane). An analytically pure sample was obtained by recrystallization from boiling toluene to give the desired product as green crystals $(0.83 \mathrm{~g}, 32 \%)$; mp 198-200 ${ }^{\circ} \mathrm{C}$; (Found: C, 46.5; H, 2.6. Anal. Calc. for $\mathrm{C}_{12} \mathrm{H}_{8} \mathrm{Se}_{2}$ : C, 46.5; $\left.\mathrm{H}, 2.6 \%\right) ; \delta_{\mathrm{H}}\left(270 \mathrm{MHz}, \mathrm{CDCl}_{3}, 25^{\circ} \mathrm{C}\right.$, $\left.\mathrm{Me}_{4} \mathrm{Si}\right) 7.21\left(1 \mathrm{H}, \mathrm{d},{ }^{3} J_{\mathrm{HH}} 7.4 \mathrm{~Hz}\right.$, Acenap 4,7-H), $7.05\left(1 \mathrm{H}, \mathrm{d},{ }^{3} J_{\mathrm{HH}} 7.2\right.$ $\mathrm{Hz}$, Acenap 3,8-H), $3.26\left(4 \mathrm{H}, \mathrm{s}, 2 \times \mathrm{CH}_{2}\right) ; \delta_{\mathrm{C}}\left(67.9 \mathrm{MHz} ; \mathrm{CDCl}_{3} ; 25^{\circ} \mathrm{C}\right.$; $\mathrm{Me}_{4} \mathrm{Si}$ ) $121.7(\mathrm{~s}), 121.2(\mathrm{~s}), 30.4\left(\mathrm{~s}\right.$, Acenap $\left.\mathrm{CH}_{2}\right) ; \delta_{\mathrm{Se}}\left(51.5 \mathrm{MHz} ; \mathrm{CDCl}_{3}\right.$; $\left.25^{\circ} \mathrm{C} ; \mathrm{Me}_{2} \mathrm{Se}\right) 424(\mathrm{~s}) ; \mathrm{m} / z\left(\mathrm{ES}^{+}\right) 311.90\left([\mathrm{M}+\mathrm{H}]^{+}, 100 \%\right), 309.91\left([\mathrm{M}]^{+}\right.$, $70 \%)$.

[Pt(PPh $)_{2} \mathbf{L 1 ]}$ (1): Super Hydride (1.1 mL of a $1.0 \mathrm{M}$ solution in THF, $1.1 \mathrm{mmol})$ was added in one portion to a solution of 5,6dihydroacenaptho[5,6-cd][1,2] dithiole $\left(\right.$ AcenapS $\left._{2}\right) \mathbf{L 1}(0.12 \mathrm{~g}, 0.56$ $\mathrm{mmol})$ in THF $(20 \mathrm{~mL})$. A colour change from bright red to pale yellow was observed, along with a small evolution of gas. The solution was transferred using a syringe to a suspension of cis-[ $\left.\mathrm{PtCl}_{2}\left(\mathrm{PPh}_{3}\right)_{2}\right](0.45 \mathrm{~g}$, $0.56 \mathrm{mmol})$ in THF $(10 \mathrm{~mL})$ and stirred for 2 days giving a yellow solution. The mixture was filtered through a silica pad and eluted with dichloromethane $(100 \mathrm{~mL})$. The filtrate was evaporated to dryness under reduced pressure and re-dissolved in a minimum amount of dichloromethane $(\sim 10 \mathrm{~mL})$. Diethyl ether $(25 \mathrm{~mL})$ and hexane $(50 \mathrm{~mL})$ were added slowly to induce precipitation. The resulting microcrystalline solid was collected by filtration and washed with diethyl ether to yield the product as a light orange powder $(0.4 \mathrm{~g}, 74 \%) ; \mathrm{mp}$ 282-284 ${ }^{\circ} \mathrm{C}$; (Found: C, 61.4; H, 4.0. Anal. Calc. for $\mathrm{C}_{48} \mathrm{H}_{38} \mathrm{P}_{2} \mathrm{PtS}_{2}: \mathrm{C}$, 61.6; H, 4.1\%); $\delta_{\mathrm{H}}\left(400 \mathrm{MHz}, \mathrm{CDCl}_{3}, 25^{\circ} \mathrm{C}, \mathrm{Me}_{4} \mathrm{Si}\right) 7.48-7.38(12 \mathrm{H}, \mathrm{m}$, $\mathrm{PPh}$ 12,16-H), 7.34-7.26 (6 H, m, PPh 14-H), 7.27 (2 H, d, ${ }^{3} J_{\mathrm{HH}} 7.3$, Acenap 4,7-H), $7.14\left(12 \mathrm{H}, \mathrm{td},{ }^{3} J_{\mathrm{HH}} 7.7,{ }^{4} J_{\mathrm{HH}} 1.8, \mathrm{PPh} 13,18-\mathrm{H}\right), 6.90$ (2 $\mathrm{H}, \mathrm{d},{ }^{3} J_{\mathrm{HH}} 7.3$, Acenap 3,8-H), $3.17(4 \mathrm{H}, \mathrm{s}$, Acenap-CH$) ; \delta_{\mathrm{C}}(75 \mathrm{MHz}$, $\mathrm{CDCl}_{3}, 25^{\circ} \mathrm{C}, \mathrm{Me}_{4} \mathrm{Si}$ ) 142.0(s), 140.7(s), 135.4-134.8 (m), 130.4 (s), 128.6-127.4 (m), 119.7(s), 30.9(s, $\left.C \mathrm{H}_{2}\right) ; \delta_{\mathrm{P}}\left(109 \mathrm{MHz}, \mathrm{CDCl}_{3}, 25^{\circ} \mathrm{C}\right.$, $\left.\mathrm{H}_{3} \mathrm{PO}_{4}\right) 23.5\left(J_{\mathrm{PPt}} 2980\right) ; \mathrm{m} / \mathrm{z}\left(\mathrm{ES}^{+}\right) 826.66\left([\mathrm{M}-\mathrm{SPh}]^{+}, 100 \%\right)$.

[Pt $\left.\left(\mathbf{P P h}_{3}\right)_{2} \mathbf{L} 2\right]$ (2): Complex 2 was prepared following a similar procedure described for $\mathbf{1}$ but with Super Hydride (1.1 mL, $1.1 \mathrm{mmol}$ ), L2 $(0.18 \mathrm{~g}, 0.56 \mathrm{mmol})$ and $c i s-\left[\mathrm{PtCl}_{2}\left(\mathrm{PPh}_{3}\right)_{2}\right](0.45 \mathrm{~g}, 0.56 \mathrm{mmol})$. The resulting solid was filtered off and washed with toluene $(5 \mathrm{~mL})$ and diethyl ether $(2 \times 10 \mathrm{~mL})$ and dried in vacuo to yield an orange powder 
(0.3 g, 54\%); mp 185-186 ${ }^{\circ} \mathrm{C}$; (Found: C, 55.9; H, 3.8. Anal. Calc. for $\left.\mathrm{C}_{48} \mathrm{H}_{38} \mathrm{PtP}_{2} \mathrm{Se}_{2}: \mathrm{C}, 56.0 ; \mathrm{H}, 3.7 \%\right) ; \delta_{\mathrm{H}}\left(400 \mathrm{MHz}, \mathrm{CDCl}_{3}, 25^{\circ} \mathrm{C}, \mathrm{Me}_{4} \mathrm{Si}\right)$ $7.51\left(2 \mathrm{H}, \mathrm{d},{ }^{3} J_{\mathrm{HH}} 7.28\right.$, Acenap 4,7-H), 7.48-7.39 (12 H, m, PPh 12,16H), 7.35-7.26 (6 H, m, PPh 14-H), $7.10\left(12 \mathrm{H}, \mathrm{t},{ }^{3} J_{\mathrm{HH}} 7.06\right.$, PPh 13,18$\mathrm{H}), 6.81\left(2 \mathrm{H}, \mathrm{d},{ }^{3} J_{\mathrm{HH}} 7.25\right.$, Acenap 3,8-H), $3.13\left(4 \mathrm{H}, \mathrm{s}, 2 \times \mathrm{CH}_{2}\right)$; $\delta_{\mathrm{C}}\left(67.9 \mathrm{MHz} ; \mathrm{CDCl}_{3} ; 25^{\circ} \mathrm{C} ; \mathrm{Me}_{4} \mathrm{Si}\right) 143.2(\mathrm{~s}), 143.7(\mathrm{t}, J$ 5.4), $130.0(\mathrm{~s})$, $128.0(\mathrm{t}, J 5.2), 119.3(\mathrm{~s}), 30.1\left(\mathrm{~s}, \mathrm{CH}_{2}\right) ; \delta_{\mathrm{P}}\left(109 \mathrm{MHz}, \mathrm{CDCl}_{3}, 25^{\circ} \mathrm{C}\right.$, $\left.\mathrm{H}_{3} \mathrm{PO}_{4}\right) 20.2\left(J_{\mathrm{PPt}} 3020\right) ; \delta_{\mathrm{Se}}\left(52 \mathrm{MHz}, \mathrm{CDCl}_{3}, 25^{\circ} \mathrm{C}, \mathrm{PhSeSePh}\right) 167.3$ $(\mathrm{pt}) ;[33] \mathrm{m} / \mathrm{z}\left(\mathrm{ES}^{+}\right) 874.00\left([\mathrm{M}-\mathrm{SePh}]^{+}, 100 \%\right)$.

[Pt(PPh $\left.\mathbf{P e})_{2} \mathbf{L 1}\right]$ (3): ): 3 was prepared following a similar procedure described for $\mathbf{1}$ but with Super Hydride $(1.1 \mathrm{~mL}, 1.1 \mathrm{mmol}), \mathbf{L 1}(0.12 \mathrm{~g}$, $0.56 \mathrm{mmol})$ and cis-[ $\left.\mathrm{PtCl}_{2}\left(\mathrm{PPh}_{2} \mathrm{Me}\right)_{2}\right](0.375 \mathrm{~g}, 0.564 \mathrm{mmol})$. The resulting micro-crystalline solid was collected by filtration and washed with diethyl ether to yield the product as a bright orange powder $(0.3 \mathrm{~g}$, $65 \%$ ); mp 275-278 ${ }^{\circ} \mathrm{C}$; (Found: C, 55.9; H, 3.8. Anal. Calc. for $\left.\mathrm{C}_{38} \mathrm{H}_{34} \mathrm{PtP}_{2} \mathrm{~S}_{2}: \mathrm{C}, 56.2 ; \mathrm{H}, 4.2 \%\right) ; \delta_{\mathrm{H}}\left(400 \mathrm{MHz}, \mathrm{CDCl}_{3}, 25^{\circ} \mathrm{C}, \mathrm{Me}_{4} \mathrm{Si}\right)$ $7.46\left(2 \mathrm{H}, \mathrm{d},{ }^{2} J_{\mathrm{HH}} 7.3\right.$, Acenap 4,7-H), 7.42-7.32 (8 H, m, PPh 12,16-H), 7.32-7.24 (8 H, m, PPh 13,18-H), 7.17 (4 H, d, ${ }^{2} J_{\mathrm{HH}} 7.3$, PPh 14-H), 6.85 $\left(2 \mathrm{H}, \mathrm{d},{ }^{2} J_{\mathrm{HH}} 7.2\right.$, Acenap 3,8-H), 3.06 (4 H, s, Acenap $\left.\mathrm{CH}_{2}\right), 1.84-1.70$ $\left(6 \mathrm{H}, \mathrm{m}, \mathrm{PCH}_{3}\right) ; \delta_{\mathrm{C}}\left(67.9 \mathrm{MHz} ; \mathrm{CDCl}_{3} ; 25^{\circ} \mathrm{C} ; \mathrm{Me}_{4} \mathrm{Si}\right) 141.9(\mathrm{~s}), 132.8(\mathrm{t}, J$ 5.5, Ph-2), 131.4(s), 130.4(s), 128.3(t, J 5.2), 120.4(s), 119.5(s), 30.3(s), $15-14.4\left(\mathrm{~m}, \mathrm{CH}_{3}\right) ; \delta_{\mathrm{P}}\left(109 \mathrm{MHz}, \mathrm{CDCl}_{3}, 25^{\circ} \mathrm{C}, \mathrm{H}_{3} \mathrm{PO}_{4}\right) 4.51\left(J_{\mathrm{PPt}} 2926\right)$; $\mathrm{m} / \mathrm{z}\left(\mathrm{ES}^{+}\right) 703.69\left([\mathrm{M}-\mathrm{SPh}]^{+}, 100 \%\right)$.

[Pt $\left.\left(\mathbf{P P h}_{2} \mathbf{M e}\right)_{2} \mathbf{L 2}\right]$ (4): 4 was prepared following a similar procedure described for 1 but with Super Hydride $(1.1 \mathrm{~mL}, 1.1 \mathrm{mmol}), \mathbf{L 2}(0.18 \mathrm{~g}$, $0.56 \mathrm{mmol})$ and cis- $\left[\mathrm{PtCl}_{2}\left(\mathrm{PPh}_{2} \mathrm{Me}\right)_{2}\right](0.38 \mathrm{~g}, 0.56 \mathrm{mmol})$. The resulting micro-crystalline solid was collected by filtration and washed with diethyl ether to yield the product as a orange powder $(0.2 \mathrm{~g}, 43 \%)$; $\mathrm{mp}$ 184-185 ${ }^{\circ} \mathrm{C}$; (Found: C, 50.3; H, 3.7. Anal. Calc. for $\mathrm{C}_{38} \mathrm{H}_{34} \mathrm{PtP}_{2} \mathrm{Se}_{2}$ : C, $50.3 ; \mathrm{H}, 3.8 \%) ; \delta_{\mathrm{H}}\left(400 \mathrm{MHz}, \mathrm{CDCl}_{3}, 25^{\circ} \mathrm{C}, \mathrm{Me}_{4} \mathrm{Si}\right) 7.82\left(2 \mathrm{H}, \mathrm{d},{ }^{3} J_{\mathrm{HH}}\right.$ 7.3, Acenap 4,7-H), 7.55-7.45 (9 H, m, PPh 14-H), 7.45-7.35 (4 H, m, PPh 12,16-H), 7.33-7.27 (8 H, m, PPh 13,18-H), $6.92\left(2 \mathrm{H}, \mathrm{d},{ }^{3} \mathrm{~J}_{\mathrm{HH}} 7.2\right.$, Acenap 3,8-H), $3.18\left(4 \mathrm{H}, \mathrm{s}\right.$, Acenap $\left.\mathrm{CH}_{2}\right), 1.91\left(6 \mathrm{H}, \mathrm{s}, \mathrm{PCH}_{3}\right) ; \delta_{\mathrm{C}}(67.9$ $\left.\mathrm{MHz} ; \mathrm{CDCl}_{3} ; 25^{\circ} \mathrm{C} ; \mathrm{Me}_{4} \mathrm{Si}\right)$ 143.4(s), 133.00-132.6(m), 130.4 (s), 128.2(t, J 5.1), 119.3(s), 30.1(s), 14.9-14.7(m, $\left.\mathrm{CH}_{3}\right) ; \delta_{\mathrm{P}}(162 \mathrm{MHz}$, $\left.\mathrm{CDCl}_{3}, 25^{\circ} \mathrm{C}, \mathrm{H}_{3} \mathrm{PO}_{4}\right) 1.22\left(J_{\mathrm{PPt}} 2958\right) ; \mathrm{m} / \mathrm{z}\left(\mathrm{ES}^{+}\right) 929.07\left([\mathrm{M}+\mathrm{Na}]^{+}\right.$, $35 \%)$.

$\left[\mathbf{P t}(\mathbf{P P h M e})_{2} \mathbf{L 1}\right](\mathbf{5}): \mathbf{5}$ was prepared following a similar procedure described for 1 but with Super Hydride $(1.1 \mathrm{~mL}, 1.1 \mathrm{mmol}), \mathbf{L 1}(0.12 \mathrm{~g}$, $0.56 \mathrm{mmol})$ and cis-[ $\left.\mathrm{PtCl}_{2}\left(\mathrm{PPhMe}_{2}\right)\right](0.31 \mathrm{~g}, 0.56 \mathrm{mmol})$. The resulting micro-crystalline solid was collected by filtration and washed with diethyl ether to yield the product as a yellow solid $(0.2,50 \%)$; $\mathrm{mp} 265$ $270{ }^{\circ} \mathrm{C}$; (Found: C, 48.8; H, 4.3. Anal. Calc. for $\mathrm{C}_{28} \mathrm{H}_{30} \mathrm{PtP}_{2} \mathrm{~S}_{2}: \mathrm{C}$, 48.9;

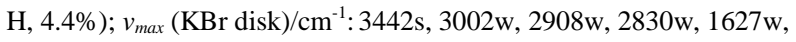
1550w, 1479w, 1429s, 1402s, 1323w, 1293w, 1228w, 1178w, 1104w, $1033 \mathrm{w}, 947 \mathrm{~s}, 906 \mathrm{vs}, 835 \mathrm{w}, 737 \mathrm{w}, 714 \mathrm{w}, 690 \mathrm{w}, 619 \mathrm{w}, 524 \mathrm{w}, 495 \mathrm{w}$, $436 \mathrm{w} ; \delta_{\mathrm{H}}\left(400 \mathrm{MHz}, \mathrm{CDCl}_{3}, 25^{\circ} \mathrm{C}, \mathrm{Me}_{4} \mathrm{Si}\right) 7.78\left(2 \mathrm{H}, \mathrm{d},{ }^{3} \mathrm{~J}_{\mathrm{HH}} 7.3\right.$, Acenap 4,7-H), 7.49-7.25 (8 H, m, PPh 12,16-H), 7.28 ( $2 \mathrm{H}, \mathrm{d},{ }^{2} J$ 4.4, $\mathrm{PPh}$ 13,18-H), 6.99 (2 H, d, ${ }^{3} \mathrm{~J}_{\mathrm{HH}} 7.2$, Acenap 3,8-H), 3.19 (4 H, s, Acenap $\left.\mathrm{CH}_{2}\right), 1.80-1.65\left(6 \mathrm{H}, \mathrm{m}, \mathrm{PCH}_{3}\right) ; \delta_{\mathrm{C}}\left(67.9 \mathrm{MHz} ; \mathrm{CDCl}_{3} ; 25^{\circ} \mathrm{C}\right.$; $\left.\mathrm{Me}_{4} \mathrm{Si}\right)$ 141.7(s), 140.7(s), 132.4(s), 132.2(s), 130.9(t, J 5.2), 130.3(s), 128.5(t, J 5.1), 127.7(t, J 6.7), 119.4(s), 30.5(s), 13.9-13.0(m, $\left.\mathrm{CH}_{3}\right)$; $\delta_{\mathrm{P}}\left(109 \mathrm{MHz}, \mathrm{CDCl}_{3}, 25^{\circ} \mathrm{C}, \mathrm{H}_{3} \mathrm{PO}_{4}\right)-13.14\left(J_{\mathrm{PPt}} 2861, J_{\mathrm{PP}} 8.4\right) ; \mathrm{m} / \mathrm{z}\left(\mathrm{ES}^{+}\right)$ $578.70\left([\mathrm{M}-\mathrm{SPh}]^{+}, 100 \%\right)$.

[Pt(PPhMe $\left.\left.)_{2}\right)_{2} \mathbf{L 2}\right](6): 6$ was prepared following a similar procedure described for $\mathbf{1}$ but with Super Hydride $(1.1 \mathrm{~mL}, 1.1 \mathrm{mmol}), \mathbf{L 2}(0.18 \mathrm{~g}$, $0.56 \mathrm{mmol})$ and $c i s-\left[\mathrm{PtCl}_{2}\left(\mathrm{PPhMe}_{2}\right)\right](0.31 \mathrm{~g}, 0.56 \mathrm{mmol})$. The resulting micro-crystalline solid was collected by filtration and washed with diethyl ether to yield a yellow solid $(0.2 \mathrm{~g}, 45 \%)$; mp $184-185^{\circ} \mathrm{C}$;
(Found: C, 42.8; H, 3.2. Anal. Calc. for C28H30PtP2Se2: C, 43.0; H, $3.9 \%) ; \delta_{\mathrm{H}}\left(400 \mathrm{MHz}, \mathrm{CDCl}_{3}, 25^{\circ} \mathrm{C}, \mathrm{Me}_{4} \mathrm{Si}\right) 7.88\left(2 \mathrm{H}, \mathrm{d},{ }^{3} J_{\mathrm{HH}} 7.2\right.$, Acenap 4,7-H ), 7.45-7.35 (4 H, m, PPh 12,16-H), 7.30-7.26 (4 H, m, $\mathrm{PPh} 13,18-\mathrm{H}), 7.20(2 \mathrm{H}, \mathrm{m}, 4-\mathrm{H}), 6.85\left(2 \mathrm{H}, \mathrm{d},{ }^{3} \mathrm{~J}_{\mathrm{HH}} 7.3\right.$, Acenap 3,8-H), $3.09\left(4 \mathrm{H}, \mathrm{s}, \mathrm{CH}_{2}\right), 1.80-1.60\left(12 \mathrm{H}, \mathrm{m}, \mathrm{PCH}_{3}\right) ; \delta_{\mathrm{C}}\left(67.9 \mathrm{MHz} ; \mathrm{CDCl}_{3}\right.$; $\left.25^{\circ} \mathrm{C} ; \mathrm{Me}_{4} \mathrm{Si}\right) 141.7(\mathrm{~s}), 140.7(\mathrm{~s}), 132.4(\mathrm{~s}), 132.2(\mathrm{~s}), 130.8(\mathrm{t}, J$ 5.2), 130.3(s), 128.5(t, J 5.1) 127.6(t, J 6.7), 119.4(s), 30.5(s), 13.8-13.7(m, $\left.\mathrm{CH}_{3}\right) ; \delta_{\mathrm{P}}\left(109 \mathrm{MHz}, \mathrm{CDCl}_{3}, 25^{\circ} \mathrm{C}, \mathrm{H}_{3} \mathrm{PO}_{4}\right)-16.22\left(J_{\mathrm{PPt}} 2895, J_{\mathrm{PA}-\mathrm{Se}} 67\right.$, $\left.J_{\mathrm{PA}-\mathrm{Se}} 40, J_{\mathrm{PP}} 12.4\right) ; \delta_{\mathrm{Se}}\left(52 \mathrm{MHz}, \mathrm{CDCl}_{3}, 25^{\circ} \mathrm{C}, \mathrm{PhSeSePh}\right)$ 426.2(pt);[33] m/z (ES $) 625.99$ ([M-SePh $\left.]^{+}, 100 \%\right)$.

\section{Crystal Structure Analyses}

X-ray crystal structures for $\mathbf{L 1}, \mathbf{L 2}$, and 6 were determined at -148(1) ${ }^{\circ} \mathrm{C}$ on the St Andrews Robotic Diffractometer[34] a Rigaku ACTOR-SM, Saturn $724 \mathrm{CCD}$ area detector with graphite monochromated Mo-K $\alpha$ radiation $(\lambda=0.71073 \AA$ ). The data was corrected for Lorentz, polarisation and absorption. Data for compounds $\mathbf{1}$ and $\mathbf{2}$ were collected at $-180(1){ }^{\circ} \mathrm{C}$ by using a Rigaku MM007 High brilliance RA generator (Mo K $\alpha$ radiation, confocal optic) and Saturn CCD system. At least a full hemisphere of data was collected using $\omega$ scans. Intensities were corrected for Lorentz, polarisation and absorption. Data for compound $\mathbf{5}$ were collected at $-148(1){ }^{\circ} \mathrm{C}$ on a Rigaku SCXmini CCD area detector with graphite monochromated Mo K $\alpha$ radiation $(\lambda=0.71073 \AA)$. The data were corrected for Lorentz, polarisation and absorption. The data for the complexes analysed was collected and processed using CrystalClear (Rigaku).[35] The structures were solved by direct methods[36] and expanded using Fourier techniques.[37] The nonhydrogen atoms were refined anisotropically. Hydrogen atoms were refined using the riding model. All calculations were performed using the CrystalStructure[38] crystallographic software package except for refinement, which was performed using SHELXL-97.[39] These X-ray data can be obtained free of charge via

www.ccdc.cam.ac.uk/conts/retrieving.html or from the Cambridge Crystallographic Data centre, 12 Union Road, Cambridge CB2 1EZ, UK; fax (+44) 1223-336-033; e-mail: deposit@ccdc.cam.ac.uk CCDC Nos:

\section{Acknowledgments}

Mass Spectrometry was performed at the University of St. Andrews Mass Spectrometry Service by Caroline Horsburgh. The work in this project was supported by the Engineering and Physical Sciences Research Council (EPSRC).

[1] P. Kilian, F. R. Knight, J. D. Woollins, Coord. Chem. Rev. 2011, 255,1387

[2] C. A. Coulson, R. Daudel, J. M. Robertson, Proc. R. Soc. London, Ser. A 1951, 207, 306;

D. W. Cruickshank, Acta Crystallogr. 1957, 10, 504;

C. P. Brock, J. D. Dunitz, Acta Crystallogr., Sect. B: Struct. Crystallogr. Cryst. Chem. 1982, 38, 2218;

J. Oddershede, S. Larsen, J. Phys. Chem. A 2004, 108, 1057.

[3] A. C. Hazell, R. G. Hazell, L. Norskov-Lauritsen, C. E. Briant, D. W. Jones, Acta Crystallogr., Sect. C: Cryst. Struct. Commun. 1986, 42,690

[4] V. Balasubramaniyan, Chem. Rev. 1966, 66, 567.

[5] P. Kilian, F. R. Knight, J. D. Woollins, Chem. Eur. J. 2011, 17 2302.

[6] J. D. Hoefelmeyer, M. Schulte, M. Tschinkl, F. P. Gabbai, Coord. Chem. Rev. 2002, 235, 93;

L. Sobczyk, J. Mol. Struct. 2010, 972, 59; 
A. L. Llamas-Saiz, C. Foces-Foces, J. Elguero, J. Mol. Struct. 1994, 328, 297;

H. A. Staab, T. Saupe, Angew. Chem. Int. Ed. 1988, 27, 865.

[7] J. Meinwald, D. Dauplaise, F. Wudl, J. J. Hauser, J. Am. Chem. Soc. 1977, 99, 255;

A. J. Ashe III, J. W. Kampf, P. M. Savla, Heteroat. Chem. 1994, 5, 113;

M. Lanfrey, Compt. Rend. 1911, 152, 92;

W. B. Price, S. Smiles, J. Chem. Soc. 1928, 2372;

A. Zweig, A. K. Hoffman, J. Org. Chem. 1965, 30, 3997;

P. Kilian, A. M. Z. Slawin, J. D. Woollins, Dalton Trans. 2006, 2175;

P. Kilian, D. Philp, A. M. Z. Slawin, J. D. Woollins, Eur. J. Inorg. Chem. 2003, 249;

P. Wawrzyniak, A. L. Fuller, A. M. Z. Slawin, P. Kilian, Inorg. Chem. 2009, 48, 2500.

[8] B. K. Teo, F. Wudl, J. H. Marshall, A. Krugger, J. Am. Chem. Soc. 1977, 99, 2349;

B. K. Teo, P. A. Snyder-Robinson, Inorg. Chem. 1978, 17, 3489;

B. K. Teo, P. A. Snyder-Robinson, J. Chem. Soc. Chem. Commun. 1979, 255;

B. K. Teo, P. A. Snyder-Robinson, Inorg. Chem. 1079, 18, 1490;

B. K. Teo, P. A. Snyder-Robinson, Inorg. Chem. 1981, 20, (4235;

B. K. Teo, P. A. Snyder-Robinson, Inorg. Chem. 1984, 23, 32.

[9] B. K. Teo, F. Wudl, J. J. Hauser, A. Krugger, J. Am. Chem. Soc. 1977, 99, 4862;

B. K. Teo, V. Bakirtzis, P. A. Snyder-Robinson, J. Am. Chem. Soc. 1983, 105, 6330.

[10] W. P. Bosman, H. G. M. van der Linden, J. Chem. Soc. Chem. Commun. 1977, 714.

[11] A. W. Gal, J. W. Gosselink, F. A. Vollenbroek, Inorg. Chim. Acta 1979, 32, 235.

[12] S. M. Aucott, H. L. Milton, S. D. Robertson, A. M. Z. Slawin, G. D. Walker, J. D. Woollins, Chem. Eur. J. 2004, 10, 1666.

[13] S. M. Aucott, H. L. Milton, S. D. Robertson, A. M. Z. Slawin, J. D. Woollins, Dalton Trans. 2004, 3347.

[14] S. M. Aucott, D. Duerden, Y. Li, A. M. Z. Slawin, J. D. Woollins, Chem. Eur. J. 2006, 12, 5495.

[15] S. D. Robertson, A. M. Z. Slawin, J. D. Woollins, Eur. J. Inorg. Chem. 2007, 247.

[16] H. Xu, J. H. K. Yip, Inorg. Chem. 2003, 42, 4492.

[17] M. Tesmer, H. Vahrenkamp, Eur. J. Inorg. Chem. 2001, 1183.

[18] S. M. Aucott, P. Kilian, H. L. Milton, S. D. Robertson, A. M. Z. Slawin, J. D. Woollins, Inorg. Chem. 2005, 44, 2710.

[19] S. D. Robertson, A. M. Z. Slawin, J. D. Woollins, Polyhedron 2006, 25, 823 .

[20] M.-L. Lechner, K. S. Athukorala Arachchige, R. A. M. Randall, F. R. Knight, M. Bühl, A. M. Z. Slawin, J. D. Woollins, Organometallics 2012, 31, 2922.

[21] L. K. Aschenbach, F. R. Knight, R. A .M. Randall, D. B. Cordes, A. Baggott, M. Bühl, A. M. Z. Slawin, J. D. Woollins, Dalton Trans. 2012, 41, 3141.

[22] F. R. Knight, R. A. M. Randall, L. Wakefield, A. M. Z. Slawin, J. D. Woollins, Inorg. Chem. 2012, submitted;

F. R. Knight, R. A. M. Randall, L. Wakefield, A. M. Z. Slawin, J. D. Woollins, Dalton Trans. 2012, submitted.
[23] Y. Aso, K. Yui, T. Miyoshi, T. Otsubo, F. Ogura, J. Tanaka, Bull. Chem. Soc. Jpn. 1988, 61, 2013.

[24] W. D. Neudorff, D. Lentz, M. Anibarro, A. D. Schlüter, Chem. Eur. J. 2003, 9, 2745.

[25] J. A. Iggo (Ed.), NMR Spectroscopy in Inorganic Chemistry, Oxford University Press Inc., New York, 1999.

[26] W. H. Hersh, J. Chem. Ed. 1997, 74, 1485.

[27] C. P. Morley, C. A. Webster, P. Douglas, K. Rofe, M. Di Vaira, Dalton Trans. 2010, 39, 3177.

[28] A. Bondi, J. Phys. Chem. 1964, 68, 441.

[29] S. M. Aucott, H. L. Milton, S. D. Robertson, A. M. Z. Slawin, J. D. Woollins, Heteroat. Chem. 2004, 15, 530.

[30] C. A. Tolman, Chem. Rev. 1977, 77, 313.

[31] H. W. Roesky, M. Andruh, Coord. Chem. Rev. 2003, 236, 91; T. Koizumi, K. Tsutsui, K. Tanaka, Eur. J. Org. Chem. 2003 , 4528 ;

C. Janiak, J. Chem. Soc. Dalton Trans. 2000, 3885.

[32] M. Nishio, CrystEngComm 2004, 6, 130;

C. Fischer, T. Gruber, W. Seichter, D. Schindler, E. Weber, Acta Crystallogr. Sect. E 2008, 64, o673;

M. Hirota, K. Sakaibara, H. Suezawa, T. Yuzuri, E. Ankai, M Nishio, J. Phys. Org. Chem. 2000, 13, 620;

H. Tsubaki, S. Tohyama, K. Koike, H. Saitoh, O. Ishitani, Dalton Trans. 2005, 385.

[33] ( $\mathrm{pt}=$ pseudo triplet) representing the coupling of ${ }^{77} \mathrm{Se}$ to the cis and trans ${ }^{31} \mathrm{P}$ nuclei, with an overlap of the central peaks, as such calculation of the coupling constants was not possible.

[34] A. L. Fuller, L. A. S. Scott-Hayward, Y. Li, M. Bühl, A. M. Z. Slawin, J. D. Woollins, J. Am. Chem. Soc. 2010, 132, 5799.

[35] CrystalClear 1.6: Rigaku Corporation, 1999. CrystalClear Software User's Guide, Molecular Structure Corporation, (c) 2000. J.W.P. Flugrath, Acta Crystallogr., Sect. D 1999, D55, 1718.

[36] SIR97: A. Altomare, M. Burla, M. Camalli, G. Cascarano, C. Giacovazzo, A. Guagliardi, A. Moliterni, G. Polidori, R. Spagna, J. Appl. Cryst. 1999, 32, 115.

[37] DIRDIF99: P. T. Beurskens, G. Admiraal, G. Beurskens, W. P. Bosman, R. de Gelder, R. Israel, J. M. M. Smits, 1999. The DIRDIF-99 program system, Technical Report of the Crystallography Laboratory, University of Nijmegen, The Netherlands.

[38] CrystalStructure 3.8.1: Crystal Structure Analysis Package, Rigaku and Rigaku/MSC (2000-2006). 9009 New Trails Dr. The Woodlands TX 77381 USA.

[39] SHELX97: G .M. Sheldrick, Acta Crystallogr., Sect. A 2008, 64, 112

Received: ((will be filled in by the editorial staff)) Published online: ((will be filled in by the editorial staff)) 
Entry for the Table of Contents ((Please choose one layout.))

\section{Layout 1:}

((Key Topic))

((Six platinum bisphosphine complexes bearing 5,6-dihydroacenaphtho[5,6-cd] 1,2-dichalcogenoles AcenapE $E_{2} \mathrm{E}=\mathrm{S}$, $\mathrm{Se}$, have been prepared, formed from metathetical addition of the dilithium precursors to cis- $\left[\mathrm{PtCl}_{2}\left(\mathrm{PR}_{3}\right)_{2}\right]\left(\mathrm{R}_{3}=\right.$ $\left.\mathrm{Ph}_{3}, \mathrm{Ph}_{2} \mathrm{Me}, \mathrm{PhMe}_{2}\right)$.))

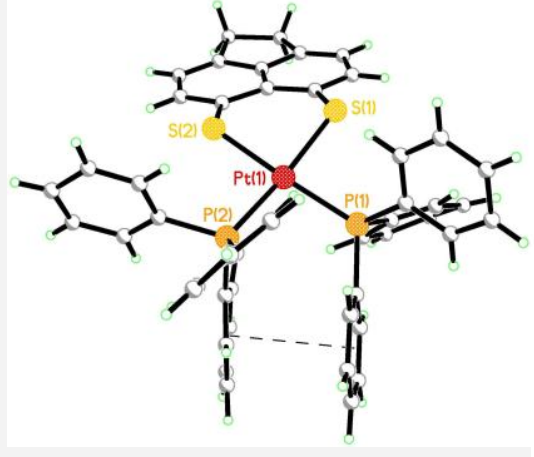

((Callum G. M. Benson, Catherine M. Schofield, Rebecca A. M. Randall, Lucy Wakefield, Fergus R. Knight, Alexandra M. Z. Slawin and J. Derek Woollins*)) ........ Page No. - Page No.

((Platinum Complexes of 5,6dihydroacenaphtho[5,6-cd]-1,2dichalcogenoles))

Keywords: ((Chalcogen / Metathesis /

\section{Layout 2:}

((Key Topic))

((Please adjust TOC Graphic to the size of this area; max. width $11.5 \mathrm{~cm})$ )

((Text for Table of Contents))
((Text for Table of Contents, Continued - max. 350 characters; not the same text as the Abstract))
((Author(s), with * for Corresponding Author(s))) ......... Page No. - Page No.

$(($ Title $))$

Keywords: ((Keyword 1 / Keyword 2 / Keyword 3 / Keyword 4 / Keyword 5)) 


\section{Supporting Information ((optional))}

\section{Experimental Section}

All experiments were carried out under an oxygen- and moisture-free nitrogen atmosphere using standard Schlenk techniques and glassware. Reagents were obtained from commercial sources and used as received. Dry solvents were collected from a MBraun solvent system. Elemental analyses were performed by Stephen Boyer at the London Metropolitan University. Infrared spectra were recorded as $\mathrm{KBr}$ discs in the range $4000-300 \mathrm{~cm}^{-1}$ on a Perkin-Elmer System 2000 Fourier transform spectrometer. ${ }^{1} \mathrm{H}$ and ${ }^{13} \mathrm{C}$ NMR spectra were recorded on a Jeol GSX $270 \mathrm{MHz}$ spectrometer with $\delta(\mathrm{H})$ and $\delta(\mathrm{C})$ referenced to external tetramethylsilane. ${ }^{31} \mathrm{P}$ and ${ }^{77}$ Se NMR spectra were recorded on a Jeol GSX $270 \mathrm{MHz}$ spectrometer with $\delta(\mathrm{P})$ and $\delta(\mathrm{Se})$ referenced to external phosphoric acid and dimethylselenide respectively. Assignments of ${ }^{13} \mathrm{C}$ and ${ }^{1} \mathrm{H}$ NMR spectra were made with the help of H-H COSY and HSQC experiments. All measurements were performed at $25^{\circ} \mathrm{C}$. All values reported for NMR spectroscopy are in parts per million (ppm). Coupling constants $(J)$ are given in Hertz (Hz). Mass spectrometry was performed by the University of St. Andrews Mass Spectrometry Service; Electrospray Mass Spectrometry (ESMS) was carried out on a Micromass LCT orthogonal accelerator time of flight mass spectrometer. Platinum metal precursors cis$\left[\mathrm{PtCl}_{2}\left(\mathrm{PR}_{3}\right)\right]\left(\mathrm{R}_{3}=\mathrm{Ph}_{3}, \mathrm{Ph}_{2} \mathrm{Me}, \mathrm{PhMe}_{2}\right)$ were prepared following standard literature procedures.[12]

5,6-dihydroacenaphtho[5,6-cd][1,2]dithiole $\left[\operatorname{AcenapS}_{2}\right](\mathbf{L 1})$ : The title compound was prepared by a method previously described.[23] To a stirred solution of 5,6-dibromoacenaphthene (5.0 g, $16.03 \mathrm{mmol})$ and TMEDA (4.8 $\mathrm{mL}, 16.03 \mathrm{mmol})$ in diethyl ether $(200 \mathrm{~mL})$ was slowly added a $2.5 \mathrm{M}$ hexane solution of $n$-butyllithium $(6.4 \mathrm{~mL}, 16.03 \mathrm{mmol})$ at $-78^{\circ} \mathrm{C}$. After the mixture was stirred for $15 \mathrm{~min}$ at this temperature, sulfur flowers $(0.51 \mathrm{~g}, 16.03 \mathrm{mmol})$ were added and stirring was continued at $-40{ }^{\circ} \mathrm{C}$ for $2 \mathrm{~h}$. The mixture was cooled again to $-78^{\circ} \mathrm{C}$, after which a $2.5 \mathrm{M}$ hexane solution of $n$-butyllithium $(6.4 \mathrm{~mL}$, $16.03 \mathrm{mmol})$ was added and the reaction mixture stirred at this temperature for $15 \mathrm{~min}$. Additional sulfur $(0.51 \mathrm{~g}, 16.03$ mmol) was added and the reaction mixture stirred for a further $2 \mathrm{~h}$ at $-40{ }^{\circ} \mathrm{C}$. The mixture was then quenched with acetic acid $(2 \mathrm{~mL})$ and exposed to an air stream overnight for oxidation. The resulting solution was concentrated under reduced pressure and after water was added, the mixture was extracted with dichloromethane. The extract was dried over anhydrous magnesium sulfate. After the solvent was removed in vacuo, the residue was purified by column chromatography on silica gel (hexane). An analytically pure sample was obtained by recrystallization from hexane to give the desired product as orange crystals $(0.70 \mathrm{~g}, 20 \%)$; mp $178-182^{\circ} \mathrm{C}$; (Found: C, 66.5; H, 3.8. Anal. Calc. for $\mathrm{C}_{12} \mathrm{H}_{8} \mathrm{~S}_{2}$ : C, 66.6; H, 3.7\%); $v_{\max }(\mathrm{KBr}$ disk)/cm $\mathrm{cm}^{-1}: 3425 \mathrm{~s}, 3040 \mathrm{w}, 2918 \mathrm{~s}, 2833 \mathrm{w}, 2375 \mathrm{w}, 1825 \mathrm{w}, 1628 \mathrm{w}, 1596 \mathrm{w}, 1561 \mathrm{~s}, 1511 \mathrm{w}, 1483 \mathrm{w}, 1450 \mathrm{w}, 1409 \mathrm{~s}, 1394 \mathrm{vs}$, 1390vs, 1321w, 1252w, 1226s, 1207s, 1141w, 1093w, 1052w, 1033s, 916w, 828vs, 801vs, 797vs, 749w, 719w, 692w, 606s, $546 \mathrm{w}, 527 \mathrm{w}, 459 \mathrm{w}, 383 \mathrm{w}, 305 \mathrm{~s} ; \delta_{\mathrm{H}}\left(270 \mathrm{MHz}, \mathrm{CDCl}_{3}, 25^{\circ} \mathrm{C}, \mathrm{Me}_{4} \mathrm{Si}\right) 7.06\left(1 \mathrm{H}, \mathrm{d},{ }^{3} J_{\mathrm{HH}} 7.5\right.$, Acenap 4,7-H), 7.02(1 H, $\mathrm{d},{ }^{3} \mathrm{~J}_{\mathrm{HH}}$ 7.2, Acenap 3,8-H), $3.29\left(4 \mathrm{H}, \mathrm{s}, 2 \times \mathrm{CH}_{2}\right) ; \delta_{\mathrm{C}}\left(67.9 \mathrm{MHz} ; \mathrm{CDCl}_{3} ; 25^{\circ} \mathrm{C} ; \mathrm{Me}_{4} \mathrm{Si}\right) 121.1(\mathrm{~s}), 116.9(\mathrm{~s}), 30.7\left(\mathrm{~s}, \mathrm{CH}_{2}\right) ; \mathrm{m} / z$ $\left(\mathrm{ES}^{+}\right) 215.87\left([\mathrm{M}]^{+}, 100 \%\right)$.

5,6-dihydroacenaphtho[5,6-cd][1,2] diselenole [AcenapSe $\mathbf{A}_{2}$ (L2): The title compound was prepared by a method previously described.[23] To a stirred solution of 5,6-dibromoacenaphthene (2.62 g, $8.40 \mathrm{mmol})$ and TMEDA (2.5 mL, $16.1 \mathrm{mmol})$ in diethyl ether $(200 \mathrm{~mL})$ was slowly added a $2.5 \mathrm{M}$ hexane solution of $n$-butyllithium $(3.4 \mathrm{~mL}, 8.40 \mathrm{mmol})$ at $-78^{\circ} \mathrm{C}$. After the mixture was stirred for $15 \mathrm{~min}$ at this temperature, selenium powder $(0.66 \mathrm{~g}, 8.40 \mathrm{mmol})$ was added and stirring was continued at $-40{ }^{\circ} \mathrm{C}$ for $2 \mathrm{~h}$. The mixture was cooled again to $-78^{\circ} \mathrm{C}$, after which a $2.5 \mathrm{M}$ hexane solution of $n$-butyllithium $(3.4 \mathrm{~mL}, 8.40 \mathrm{mmol}$ ) was added and the reaction mixture stirred at this temperature for $15 \mathrm{~min}$. Additional selenium powder $(0.66 \mathrm{~g}, 8.40 \mathrm{mmol})$ was added and the reaction mixture stirred for a further $2 \mathrm{~h}$ at $-40{ }^{\circ} \mathrm{C}$. The mixture was then quenched with acetic acid $(2 \mathrm{~mL})$ and exposed to an air stream overnight for oxidation. The resulting solution was concentrated under reduced pressure and after water was added, the mixture was extracted with dichloromethane. The extract was dried over anhydrous magnesium sulfate. After the solvent was removed in vacuo, the residue was purified by column chromatography on silica gel (hexane/dichloromethane). An analytically pure sample was obtained by recrystallization from boiling toluene to give the desired product as green crystals $(0.83 \mathrm{~g}, 32 \%)$; mp 198-200 ${ }^{\circ} \mathrm{C}$; (Found: $\mathrm{C}, 46.5 ; \mathrm{H}, 2.6$. Anal. Calc. for $\mathrm{C}_{12} \mathrm{H}_{8} \mathrm{Se}_{2}$ : $\mathrm{C}_{\text {, }}$ $46.5 ; \mathrm{H}, 2.6 \%) ; v_{\max }\left(\mathrm{KBr}\right.$ disk)/cm ${ }^{-1}: 2914 \mathrm{~s}, 2829 \mathrm{w}, 1829 \mathrm{w}, 1564 \mathrm{vs}, 1479 \mathrm{w}, 1445 \mathrm{w}, 1415 \mathrm{vs}, 1405 \mathrm{vs}, 1377 \mathrm{vs}, 1322 \mathrm{~s}, 1251 \mathrm{w}$, 1225 s, 1093w, 1043w, 1019s, 913w, 830vs, 799vs, 745s, 728s, 700s, 600s, 496s, 463w; $\delta_{\mathrm{H}}\left(270 \mathrm{MHz}, \mathrm{CDCl}_{3}, 25^{\circ} \mathrm{C}, \mathrm{Me}_{4} \mathrm{Si}\right)$ $7.21\left(1 \mathrm{H}, \mathrm{d},{ }^{3} J_{\mathrm{HH}} 7.4 \mathrm{~Hz}\right.$, Acenap 4,7-H), $7.05\left(1 \mathrm{H}, \mathrm{d},{ }^{3} J_{\mathrm{HH}} 7.2 \mathrm{~Hz}\right.$, Acenap 3,8-H), $3.26(4 \mathrm{H}, \mathrm{s}, 2$ x CH$) ; \delta_{\mathrm{C}}(67.9 \mathrm{MHz}$; $\left.\mathrm{CDCl}_{3} ; 25^{\circ} \mathrm{C} ; \mathrm{Me}_{4} \mathrm{Si}\right) 121.7(\mathrm{~s}), 121.2(\mathrm{~s}), 30.4\left(\mathrm{~s}\right.$, Acenap $\left.\mathrm{CH}_{2}\right) ; \delta_{\mathrm{Se}}\left(51.5 \mathrm{MHz} ; \mathrm{CDCl}_{3} ; 25^{\circ} \mathrm{C} ; \mathrm{Me}_{2} \mathrm{Se}\right) 424(\mathrm{~s}) ; \mathrm{m} / z\left(\mathrm{ES}^{+}\right)$ $311.90\left([\mathrm{M}+\mathrm{H}]^{+}, 100 \%\right), 309.91\left([\mathrm{M}]^{+}, 70 \%\right)$.

[Pt $\left(\mathbf{P P h}_{3}\right)_{2} \mathbf{L 1}$ (1): Super Hydride (1.1 mL of a 1.0 M solution in THF, $\left.1.1 \mathrm{mmol}\right)$ was added in one portion to a solution of 5,6-dihydroacenaptho[5,6-cd][1,2]dithiole $\left(\right.$ AcenapS $\left._{2}\right) \mathbf{L 1}(0.12 \mathrm{~g}, 0.56 \mathrm{mmol})$ in THF $(20 \mathrm{~mL})$. A colour change from bright red to pale yellow was observed, along with a small evolution of gas. The solution was transferred using a syringe to a suspension of cis-[ $\left.\mathrm{PtCl}_{2}\left(\mathrm{PPh}_{3}\right)_{2}\right](0.45 \mathrm{~g}, 0.56 \mathrm{mmol})$ in THF $(10 \mathrm{~mL})$ and stirred for 2 days giving a yellow solution. The mixture was filtered through a silica pad and eluted with dichloromethane $(100 \mathrm{~mL})$. The filtrate was evaporated to dryness under reduced pressure and re-dissolved in a minimum amount of dichloromethane $(\sim 10 \mathrm{~mL})$. Diethyl ether $(25 \mathrm{~mL})$ and hexane $(50 \mathrm{~mL})$ were added slowly to induce precipitation. The resulting micro-crystalline solid was collected by filtration and washed with diethyl ether to yield the product as a light orange powder $(0.4 \mathrm{~g}, 74 \%) ; \mathrm{mp} 282-284{ }^{\circ} \mathrm{C} ;(\mathrm{Found}$ : $\mathrm{C}, 61.4 ; \mathrm{H}$, 
4.0. Anal. Calc. for $\mathrm{C}_{48} \mathrm{H}_{38} \mathrm{P}_{2} \mathrm{PtS}_{2}$ : C, 61.6; H, 4.1\%); $v_{\max }\left(\mathrm{KBr}\right.$ disk)/cm ${ }^{-1}$ : 3668s, 3286w, 2972w, 2894w, 2355w, 1863w, $1694 \mathrm{w}, 1603 \mathrm{w}, 1508 \mathrm{w}, 1565 \mathrm{w}, 1503 \mathrm{w}, 1447 \mathrm{vs}, 1421 \mathrm{~s}, 1391 \mathrm{w}, 1320 \mathrm{w}, 1296 \mathrm{w}, 1237 \mathrm{w}, 1203 \mathrm{w}, 1170 \mathrm{w}, 1113 \mathrm{~s}, 1079 \mathrm{~s}, 1011 \mathrm{w}$, 980w, 863w, 768w, 714vs, 675vs, 552vs, 531vs, 502s, 485s, 404w, 281s; $\delta_{\mathrm{H}}\left(400 \mathrm{MHz}, \mathrm{CDCl}_{3}, 25^{\circ} \mathrm{C}, \mathrm{Me}_{4} \mathrm{Si}\right) 7.48-7.38(12 \mathrm{H}$, m, PPh 12,16-H), 7.34-7.26 (6 H, m, PPh 14-H), 7.27 (2 H, d, ${ }^{3} J_{\mathrm{HH}} 7.3$, Acenap 4,7-H), $7.14\left(12 \mathrm{H}, \mathrm{td},{ }^{3} J_{\mathrm{HH}} 7.7,{ }^{4} J_{\mathrm{HH}} 1.8, \mathrm{P} P h\right.$ 13,18-H), $6.90\left(2 \mathrm{H}, \mathrm{d},{ }^{3} \mathrm{~J}_{\mathrm{HH}}\right.$ 7.3, Acenap 3,8-H), 3.17 (4 H, s, Acenap-CH $\mathrm{CH}_{2} ; \delta_{\mathrm{C}}\left(75 \mathrm{MHz}, \mathrm{CDCl}_{3}, 25^{\circ} \mathrm{C}, \mathrm{Me}_{4} \mathrm{Si}\right) 142.0(\mathrm{~s})$, 140.7(s), 135.4-134.8 (m), 130.4 (s), 128.6-127.4 (m), 119.7(s), 30.9(s, $\left.C_{2}\right) ; \delta_{\mathrm{P}}\left(109 \mathrm{MHz}, \mathrm{CDCl}_{3}, 25^{\circ} \mathrm{C}, \mathrm{H}_{3} \mathrm{PO}_{4}\right) 23.5\left(J_{\mathrm{PPt}}\right.$ 2980); m/z (ES $\left.{ }^{+}\right) 826.66\left([\mathrm{M}-\mathrm{SPh}]^{+}, 100 \%\right)$.

[Pt(PPh $\left.)_{2} \mathbf{L} 2\right]$ (2): Super Hydride (1.1 mL of a 1.0 M solution in THF, $\left.1.1 \mathrm{mmol}\right)$ was added in one portion to a solution of 5,6-dihydroacenaptho[5,6-cd][1,2]diselenole (AcenapSe $)_{2} \mathbf{L 2}(0.18 \mathrm{~g}, 0.56 \mathrm{mmol})$ in THF $(20 \mathrm{~mL})$. A colour change from bright red to pale yellow was observed, along with a small evolution of gas. The solution was transferred using a syringe to a suspension of cis-[ $\left.\mathrm{PtCl}_{2}\left(\mathrm{PPh}_{3}\right)_{2}\right](0.45 \mathrm{~g}, 0.56 \mathrm{mmol})$ in THF $(10 \mathrm{~mL})$ and stirred for 2 days giving a yellow solution. The mixture was filtered through a silica pad and eluted with dichloromethane $(100 \mathrm{~mL})$. The filtrate was evaporated to dryness under reduced pressure and re-dissolved in a minimum amount of dichloromethane $(\sim 10 \mathrm{~mL})$. Diethyl ether $(25 \mathrm{~mL})$ and hexane $(50 \mathrm{~mL})$ were added slowly to induce precipitation. The resulting solid was filtered off and washed with toluene $(5$ $\mathrm{mL})$ and diethyl ether $(2 \times 10 \mathrm{~mL})$ and dried in vacuo to yield an orange powder $(0.3 \mathrm{~g}, 54 \%) ; \mathrm{mp} 185-186{ }^{\circ} \mathrm{C}$; (Found: $\mathrm{C}$, 55.9; H, 3.8. Anal. Calc. for $\mathrm{C}_{48} \mathrm{H}_{38} \mathrm{PtP}_{2} \mathrm{Se}_{2}$ : C, 56.0; $\left.\mathrm{H}, 3.7 \%\right) ; v_{\max }\left(\mathrm{KBr}\right.$ disk)/cm ${ }^{-1}$ : 3237w, 2746w, 1997w, 1858w, 1767w, $1694 \mathrm{w}, 1606 \mathrm{w}, 1562 \mathrm{w}, 1494 \mathrm{~s}, 1446 \mathrm{vs}, 1419 \mathrm{~s}, 1395 \mathrm{w}, 1349 \mathrm{w}, 1288 \mathrm{w}, 1236 \mathrm{w}, 1201 \mathrm{~s}, 1172 \mathrm{w}, 1110 \mathrm{vs}, 1077 \mathrm{vs}, 1008 \mathrm{w}, 939 \mathrm{~s}$, $884 \mathrm{~s}, 826 \mathrm{w}, 765 \mathrm{~s}, 721 \mathrm{vs}, 667 \mathrm{vs}, 551 \mathrm{vs}, 530 \mathrm{vs}, 501 \mathrm{~s}, 480 \mathrm{vs}, 404 \mathrm{w} ; \delta_{\mathrm{H}}\left(400 \mathrm{MHz}, \mathrm{CDCl}_{3}, 25^{\circ} \mathrm{C}, \mathrm{Me}_{4} \mathrm{Si}\right) 7.51\left(2 \mathrm{H}, \mathrm{d},{ }^{3} J_{\mathrm{HH}}\right.$ 7.28, Acenap 4,7-H), 7.48-7.39 (12 H, m, PPh 12,16-H), 7.35-7.26 (6 H, m, PPh 14-H), $7.10\left(12 \mathrm{H}, \mathrm{t},{ }^{3} J_{\mathrm{HH}} 7.06, \mathrm{PPh} 13,18-\right.$ $\mathrm{H}), 6.81\left(2 \mathrm{H}, \mathrm{d},{ }^{3} J_{\mathrm{HH}} 7.25\right.$, Acenap 3,8-H), $3.13\left(4 \mathrm{H}, \mathrm{s}, 2 \times \mathrm{CH}_{2}\right) ; \delta_{\mathrm{C}}\left(67.9 \mathrm{MHz} ; \mathrm{CDCl}_{3} ; 25^{\circ} \mathrm{C} ; \mathrm{Me}_{4} \mathrm{Si}\right) 143.2(\mathrm{~s}), 143.7(\mathrm{t}, J$ 5.4), $130.0(\mathrm{~s}), 128.0(\mathrm{t}, J 5.2), 119.3(\mathrm{~s}), 30.1\left(\mathrm{~s}, \mathrm{CH}_{2}\right) ; \delta_{\mathrm{P}}\left(109 \mathrm{MHz}, \mathrm{CDCl}_{3}, 25^{\circ} \mathrm{C}, \mathrm{H}_{3} \mathrm{PO}_{4}\right) 20.2\left(J_{\mathrm{PPt}} 3020\right) ; \delta_{\mathrm{Se}}(52 \mathrm{MHz}$, $\left.\mathrm{CDCl}_{3}, 25^{\circ} \mathrm{C}, \mathrm{PhSeSePh}\right) 167.3(\mathrm{pt}) ; \mathrm{m} / \mathrm{z}\left(\mathrm{ES}^{+}\right) 874.00\left([\mathrm{M}-\mathrm{SePh}]^{+}, 100 \%\right)$.

[Pt(PPh $\mathbf{P M e}_{2} \mathbf{L 1}$ (3): Super Hydride (1.1 mL of a 1.0 M solution in THF, $1.1 \mathrm{mmol}$ ) was added in one portion to a solution of $\left(\right.$ AcenapS $\left._{2}\right) \mathbf{L 1}(0.12 \mathrm{~g}, 0.56 \mathrm{mmol})$ in THF $(20 \mathrm{~mL})$. A colour change from bright red to pale yellow was observed, along with a small evolution of gas. The solution was transferred using a syringe to a suspension of $c i s-\left[\mathrm{PtCl}_{2}\left(\mathrm{PPh}_{2} \mathrm{Me}_{2}\right](0.375 \mathrm{~g}\right.$, $0.564 \mathrm{mmol})$ in THF $(10 \mathrm{~mL})$ and stirred for 2 days giving a yellow solution. The mixture was filtered through a silica pad and eluted with dichloromethane $(100 \mathrm{~mL})$. The filtrate was evaporated to dryness under reduced pressure and re-dissolved in a minimum amount of dichloromethane $(\sim 10 \mathrm{~mL})$. Diethyl ether $(25 \mathrm{~mL})$ and hexane $(50 \mathrm{~mL})$ were added slowly to induce precipitation. The resulting micro-crystalline solid was collected by filtration and washed with diethyl ether to yield the product as a bright orange powder $(0.3 \mathrm{~g}, 65 \%)$; $\mathrm{mp} 275-278{ }^{\circ} \mathrm{C}$; (Found: $\mathrm{C}, 55.9 ; \mathrm{H}, 3.8$. Anal. Calc. for $\mathrm{C}_{38} \mathrm{H}_{34} \mathrm{PtP} \mathrm{P}_{2} \mathrm{~S}_{2}$ : C, $56.2 ; \mathrm{H}, 4.2 \%) ; v_{\max }\left(\mathrm{KBr}\right.$ disk)/cm $\mathrm{cm}^{-1}: 3421 \mathrm{vs}, 3051 \mathrm{w}, 2920 \mathrm{w}, 2670 \mathrm{w}, 1638 \mathrm{w}, 1592 \mathrm{w}, 1483 \mathrm{w}, 1435 \mathrm{~s}, 1405 \mathrm{w}, 1353 \mathrm{w}, 1287 \mathrm{w}$, $1228 \mathrm{w}, 1184 \mathrm{w}, 1103 \mathrm{~s}, 1024 \mathrm{w}, 994 \mathrm{w}, 890 \mathrm{vs}, 841 \mathrm{w}, 739 \mathrm{~s}, 693 \mathrm{vs}, 619 \mathrm{w}, 513 \mathrm{~s}, 452 \mathrm{w}, 326 \mathrm{w} ; \delta_{\mathrm{H}}\left(400 \mathrm{MHz} \mathrm{CDCl}_{3}, 25{ }^{\circ} \mathrm{C}\right.$, $\left.\mathrm{Me}_{4} \mathrm{Si}\right) 7.46\left(2 \mathrm{H}, \mathrm{d},{ }^{2} J_{\mathrm{HH}}\right.$ 7.3, Acenap 4,7-H), 7.42-7.32 (8 H, m, PPh 12,16-H), 7.32-7.24 (8 H, m, PPh 13,18-H), 7.17 (4 H, $\left.\mathrm{d},{ }^{2} J_{\mathrm{HH}} 7.3, \mathrm{PPh} 14-\mathrm{H}\right), 6.85\left(2 \mathrm{H}, \mathrm{d},{ }^{2} J_{\mathrm{HH}} 7.2\right.$, Acenap 3,8-H), $3.06\left(4 \mathrm{H}, \mathrm{s}\right.$, Acenap $\left.\mathrm{CH}_{2}\right), 1.84-1.70\left(6 \mathrm{H}, \mathrm{m}, \mathrm{PC} H_{3}\right) ; \delta_{\mathrm{C}}(67.9$ $\left.\mathrm{MHz} ; \mathrm{CDCl}_{3} ; 25^{\circ} \mathrm{C} ; \mathrm{Me}_{4} \mathrm{Si}\right) 141.9(\mathrm{~s}), 132.8(\mathrm{t}, \mathrm{J}$ 5.5, Ph-2), 131.4(s), 130.4(s), 128.3(t, J 5.2), 120.4(s), 119.5(s), 30.3(s), $15-$ $14.4\left(\mathrm{~m}, \mathrm{CH}_{3}\right) ; \delta_{\mathrm{P}}\left(109 \mathrm{MHz}, \mathrm{CDCl}_{3}, 25^{\circ} \mathrm{C}, \mathrm{H}_{3} \mathrm{PO}_{4}\right) 4.51\left(J_{\mathrm{PPt}} 2926\right) ; \mathrm{m} / \mathrm{z}\left(\mathrm{ES}^{+}\right) 703.69\left([\mathrm{M}-\mathrm{SPh}]^{+}, 100 \%\right)$.

[Pt(PPh $\left.{ }_{2} \mathbf{M e}\right)_{2} \mathbf{L 2}$ ] (4): Super Hydride (1.1 mL of a 1.0 M solution in THF, $\left.1.1 \mathrm{mmol}\right)$ was added in one portion to a solution of $\left(\right.$ AcenapSe $\left._{2}\right) \mathbf{L 2}(0.18 \mathrm{~g}, 0.56 \mathrm{mmol})$ in THF $(20 \mathrm{~mL})$. A colour change from bright red to pale yellow was observed, along with a small evolution of gas. The solution was transferred using a syringe to a suspension of $\operatorname{cis}$ - $\left[\mathrm{PtCl}_{2}\left(\mathrm{PPh}_{2} \mathrm{Me}_{2}\right](0.38 \mathrm{~g}\right.$, $0.56 \mathrm{mmol})$ in THF $(10 \mathrm{~mL})$ and stirred for 2 days giving a yellow solution. The mixture was filtered through a silica pad and eluted with dichloromethane $(100 \mathrm{~mL})$. The filtrate was evaporated to dryness under reduced pressure and re-dissolved in a minimum amount of dichloromethane $(\sim 10 \mathrm{~mL})$. Diethyl ether $(25 \mathrm{~mL})$ and hexane $(50 \mathrm{~mL})$ were added slowly to induce precipitation. The resulting micro-crystalline solid was collected by filtration and washed with diethyl ether to yield the product as a orange powder $(0.2 \mathrm{~g}, 43 \%)$; mp $184-185{ }^{\circ} \mathrm{C}$; (Found: $\mathrm{C}, 50.3 ; \mathrm{H}, 3.7$. Anal. Calc. for $\mathrm{C}_{38} \mathrm{H}_{34} \mathrm{PtP}_{2} \mathrm{Se}_{2}: \mathrm{C}_{\text {, } 50.3 ;} \mathrm{H}$, $3.8 \%) ; v_{\max }\left(\mathrm{KBr}\right.$ disk)/cm $\mathrm{cm}^{-1}: 3425 \mathrm{~s}, 3053 \mathrm{w}, 2922 \mathrm{w}, 2844 \mathrm{w}, 1632 \mathrm{w}, 1479 \mathrm{w}, 1434 \mathrm{vs}, 1401 \mathrm{w}, 1332 \mathrm{w}, 1305 \mathrm{w}, 1279 \mathrm{w}, 1255 \mathrm{w}$, $1186 \mathrm{w}, 1159 \mathrm{w}, 1099 \mathrm{vs}, 1024 \mathrm{w}, 1000 \mathrm{w}, 884 \mathrm{vs}, 836 \mathrm{w}, 806 \mathrm{w}, 734 \mathrm{~s}, 689 \mathrm{~s}, 608 \mathrm{w}, 507 \mathrm{~s}, 447 \mathrm{w}, 333 \mathrm{w} ; \delta_{\mathrm{H}}\left(400 \mathrm{MHz} \mathrm{CDCl}_{3}\right.$, $\left.25^{\circ} \mathrm{C}, \mathrm{Me}_{4} \mathrm{Si}\right) 7.82\left(2 \mathrm{H}, \mathrm{d},{ }^{3} J_{\mathrm{HH}}\right.$ 7.3, Acenap 4,7-H), 7.55-7.45 (9 H, m, PPh 14-H), 7.45-7.35 (4 H, m, PPh 12,16-H), 7.33$7.27(8 \mathrm{H}, \mathrm{m}, \mathrm{PPh} 13,18-\mathrm{H}), 6.92\left(2 \mathrm{H}, \mathrm{d},{ }^{3} J_{\mathrm{HH}} 7.2\right.$, Acenap 3,8-H), $3.18\left(4 \mathrm{H}, \mathrm{s}\right.$, Acenap $\left.\mathrm{CH}_{2}\right), 1.91\left(6 \mathrm{H}, \mathrm{s}, \mathrm{PC} H_{3}\right) ; \delta_{\mathrm{C}}(67.9$ $\left.\mathrm{MHz} ; \mathrm{CDCl}_{3} ; 25^{\circ} \mathrm{C} ; \mathrm{Me}_{4} \mathrm{Si}\right)$ 143.4(s), 133.00-132.6(m), $130.4(\mathrm{~s}), 128.2\left(\mathrm{t}, J\right.$ 5.1), 119.3(s), 30.1(s), 14.9-14.7(m, CH $H_{3}$; $\delta_{\mathrm{P}}\left(162 \mathrm{MHz}, \mathrm{CDCl}_{3}, 25^{\circ} \mathrm{C}, \mathrm{H}_{3} \mathrm{PO}_{4}\right) 1.22\left(J_{\mathrm{PPt}} 2958\right) ; \mathrm{m} / \mathrm{z}\left(\mathrm{ES}^{+}\right) 929.07\left([\mathrm{M}+\mathrm{Na}]^{+}, 35 \%\right)$.

[Pt(PPhMe $)_{2} \mathbf{L 1}$ ] (5): Super Hydride (1.1 mL of a 1.0 M solution in THF, $1.1 \mathrm{mmol}$ ) was added in one portion to a solution of $\left(\right.$ AcenapS $\left.\mathrm{S}_{2}\right) \mathbf{L 1}(0.12 \mathrm{~g}, 0.56 \mathrm{mmol})$ in THF $(20 \mathrm{~mL})$. A colour change from bright red to pale yellow was observed, along with a small evolution of gas. The solution was transferred using a syringe to a suspension of cis- $\left[\mathrm{PtCl}_{2}\left(\mathrm{PPhMe}_{2}\right)\right](0.31 \mathrm{~g}$, $0.56 \mathrm{mmol})$ in THF $(10 \mathrm{~mL})$ and stirred for 2 days giving a yellow solution. The mixture was filtered through a silica pad and eluted with dichloromethane $(100 \mathrm{~mL})$. The filtrate was evaporated to dryness under reduced pressure and re-dissolved in a minimum amount of dichloromethane $(\sim 10 \mathrm{~mL})$. Diethyl ether $(25 \mathrm{~mL})$ and hexane $(50 \mathrm{~mL})$ were added slowly to induce precipitation. The resulting micro-crystalline solid was collected by filtration and washed with diethyl ether to yield the product as a yellow solid $\left(0.2,50 \%\right.$ ); $\mathrm{mp} 265-270{ }^{\circ} \mathrm{C}$; (Found: $\mathrm{C}, 48.8 ; \mathrm{H}, 4.3$. Anal. Calc. for $\mathrm{C}_{28} \mathrm{H}_{30} \mathrm{PtP}_{2} \mathrm{~S}_{2}$ : $\mathrm{C}, 48.9 ; \mathrm{H}_{\text {, }}$ $4.4 \%) ; v_{\max }\left(\mathrm{KBr}\right.$ disk)/cm $\mathrm{cm}^{-1}: 3442 \mathrm{~s}, 3002 \mathrm{w}, 2908 \mathrm{w}, 2830 \mathrm{w}, 1627 \mathrm{w}, 1550 \mathrm{w}, 1479 \mathrm{w}, 1429 \mathrm{~s}, 1402 \mathrm{~s}, 1323 \mathrm{w}, 1293 \mathrm{w}, 1228 \mathrm{w}$, 
$1178 \mathrm{w}, 1104 \mathrm{w}, 1033 \mathrm{w}, 947 \mathrm{~s}, 906 \mathrm{vs}, 835 \mathrm{w}, 737 \mathrm{w}, 714 \mathrm{w}, 690 \mathrm{w}, 619 \mathrm{w}, 524 \mathrm{w}, 495 \mathrm{w}, 436 \mathrm{w} ; \delta_{\mathrm{H}}\left(400 \mathrm{MHz} \mathrm{CDCl}_{3}, 25{ }^{\circ} \mathrm{C}\right.$, $\left.\mathrm{Me}_{4} \mathrm{Si}\right) 7.78\left(2 \mathrm{H}, \mathrm{d},{ }^{3} J_{\mathrm{HH}}\right.$ 7.3, Acenap 4,7-H), 7.49-7.25 (8 H, m, PPh 12,16-H), 7.28 (2 H, d, ${ }^{2} J$ 4.4, PPh 13,18-H), 6.99 (2 H, $\mathrm{d},{ }^{3} \mathrm{~J}_{\mathrm{HH}}$ 7.2, Acenap 3,8-H), $3.19\left(4 \mathrm{H}, \mathrm{s}\right.$, Acenap $\left.\mathrm{CH}_{2}\right), 1.80-1.65\left(6 \mathrm{H}, \mathrm{m}, \mathrm{PCH}_{3}\right) ; \delta_{\mathrm{C}}\left(67.9 \mathrm{MHz} ; \mathrm{CDCl}_{3} ; 25^{\circ} \mathrm{C} ; \mathrm{Me}_{4} \mathrm{Si}\right)$ 141.7(s), 140.7(s), 132.4(s), 132.2(s), 130.9(t, J 5.2), 130.3(s), 128.5(t, J 5.1), 127.7(t, J 6.7), 119.4(s), 30.5(s), 13.9-13.0(m, $\left.\mathrm{CH}_{3}\right) ; \delta_{\mathrm{P}}\left(109 \mathrm{MHz}, \mathrm{CDCl}_{3}, 25^{\circ} \mathrm{C}, \mathrm{H}_{3} \mathrm{PO}_{4}\right)-13.14\left(J_{\mathrm{PPt}} 2861, J_{\mathrm{PP}} 8.4\right) ; \mathrm{m} / \mathrm{z}\left(\mathrm{ES}^{+}\right) 578.70\left([\mathrm{M}-\mathrm{SPh}]^{+}, 100 \%\right)$.

[Pt(PPhMe $)_{2} \mathbf{L 2}$ 2] (6): Super Hydride (1.1 mL of a 1.0 M solution in THF, $1.1 \mathrm{mmol}$ ) was added in one portion to a solution of $\left(\right.$ AcenapSe $\left._{2}\right) \mathbf{L 2}(0.18 \mathrm{~g}, 0.56 \mathrm{mmol})$ in THF $(20 \mathrm{~mL})$. A colour change from bright red to pale yellow was observed, along with a small evolution of gas. The solution was transferred using a syringe to a suspension of cis- $\left[\mathrm{PtCl}_{2}\left(\mathrm{PPhMe}_{2}\right)\right](0.31 \mathrm{~g}$, $0.56 \mathrm{mmol})$ in THF $(10 \mathrm{~mL})$ and stirred for 2 days giving a yellow solution. The mixture was filtered through a silica pad and eluted with dichloromethane $(100 \mathrm{~mL})$. The filtrate was evaporated to dryness under reduced pressure and re-dissolved in a minimum amount of dichloromethane $(\sim 10 \mathrm{~mL})$. Diethyl ether $(25 \mathrm{~mL})$ and hexane $(50 \mathrm{~mL})$ were added slowly to induce precipitation. The resulting micro-crystalline solid was collected by filtration and washed with diethyl ether to yield a yellow solid (0.2 g, 45\%); mp 184-185 ${ }^{\circ} \mathrm{C}$; (Found: C, 42.8; H, 3.2. Anal. Calc. for C28H30PtP2Se2: C, 43.0; H, 3.9\%); vmax (KBr disk)/cm-1: 3439s, 3044w, 3008w, 2961w, 2917w, 2272w, 1549w, 1479w, 1433s, 1328w, 1228w, 1186w, 1106s, 949vs, 906vs, 841s, 745s, 716w, 690w, 496w, 441w; $\delta_{\mathrm{H}}\left(400 \mathrm{MHz}, \mathrm{CDCl}_{3}, 25^{\circ} \mathrm{C}, \mathrm{Me}_{4} \mathrm{Si}\right) 7.88\left(2 \mathrm{H}, \mathrm{d},{ }^{3} J_{\mathrm{HH}} 7.2\right.$, Acenap 4,7-H $)$, 7.45-7.35 (4 H, m, PPh 12,16-H), 7.30-7.26 (4 H, m, PPh 13,18-H), 7.20 (2 H, m, 4-H), 6.85 (2 H, d, ${ }^{3} J_{\mathrm{HH}} 7.3$, Acenap 3,8-H), $3.09\left(4 \mathrm{H}, \mathrm{s}, \mathrm{CH}_{2}\right), 1.80-1.60(12 \mathrm{H}, \mathrm{m}, \mathrm{PCH}) ; \delta_{\mathrm{C}}\left(67.9 \mathrm{MHz} ; \mathrm{CDCl}_{3} ; 25^{\circ} \mathrm{C} ; \mathrm{Me}_{4} \mathrm{Si}\right) 141.7(\mathrm{~s}), 140.7(\mathrm{~s}), 132.4(\mathrm{~s}), 132.2(\mathrm{~s})$, $130.8\left(\mathrm{t}, J\right.$ 5.2), 130.3(s), 128.5(t, J 5.1) 127.6(t, J 6.7), 119.4(s), 30.5(s), 13.8-13.7(m, $\left.C_{3}\right) ; \delta_{\mathrm{P}}\left(109 \mathrm{MHz}, \mathrm{CDCl}_{3}, 25^{\circ} \mathrm{C}\right.$, $\left.\mathrm{H}_{3} \mathrm{PO}_{4}\right)-16.22\left(J_{\mathrm{PPt}} 2895, J_{\mathrm{PA}-\mathrm{Se}} 67, J_{\mathrm{PA}^{\prime}-\mathrm{Se}} 40, J_{\mathrm{PP}} 12.4\right) ; \delta_{\mathrm{Se}}\left(52 \mathrm{MHz}, \mathrm{CDCl}_{3}, 25^{\circ} \mathrm{C}, \mathrm{PhSeSePh}\right) 426.2(\mathrm{pt}) ; \mathrm{m} / \mathrm{z}\left(\mathrm{ES}^{+}\right) 625.99$ $\left([\mathrm{M}-\mathrm{SePh}]^{+}, 100 \%\right)$. 